\title{
Határidős devizapiac Magyarországon: általános jellemzők és a COVID-válság hatása*
}

\author{
Boldizsár Anna - Kocsis Zalán - Nagy-Kékesi Zsuzsa - Sztanó Gábor
}

Tanulmányunk a hazai határidős devizapiac alapvető jellemzőivel, szerkezetével és időbeli trendjeivel foglalkozik. Bemutatjuk, hogy a külkereskedelemben aktív vállalatok mellett elsősorban a befektetési alapok váltak a piac meghatározó szereplöivé. Mindkét szektor kereskedésében fellelhetök fedezeti és - a forint stabilitására vonatkozó várakozásokon alapuló - spekulativ motívumok. A vállalatok ugyanakkor érzékenyebben reagálnak a forward-piacon az árfolyam változásaira, mint a pénzügyi szereplők. Válságokban, így 2020 márciusában a koronavírus terjedése miatt tapasztalt globális pénzügyi turbulenciában is jellemzö a spekulativ kereskedés mérséklődése. A forint régiós devizákkal együtt mutatott március végi leértékelödése során a külkereskedelemben aktiv vállalatok nem növelték határidős devizapozíciójukat, miközben a befektetési alapok óvatossági megfontolásból, illetve a nemzetközi eszközök értékcsökkenése és likviditási sokkok (befektetésijegy-visszaváltások, megugró fedezeti követelményeik) miatt forint elleni pozícióikat növelték.

Journal of Economic Literature (JEL) kódok: C32, D84, F31, G32

Kulcsszavak: határidős devizapiac, árfolyamkitettség, befektetési alapok, időben változó paraméter modell, COVID-válság

\section{Bevezetés}

Tanulmányunk a hazai határidős devizapiaccal foglalkozik, ennek a piacnak a szerkezetét, trendjeit, szereplői viselkedési mintáit, motivációit igyekszik bemutatni.

A határidős devizapiac több szempontból fontos terület a hazai reálgazdasági-pénzügyi szereplők és a jegybank számára is. Szerepet tölt be a hazai külkereskede-

\footnotetext{
* A jelen kiadványban megjelenő írások a szerzők nézeteit tartalmazzák, ami nem feltétlenül egyezik a Magyar Nemzeti Bank hivatalos álláspontjával.
}

Boldizsár Anna a Magyar Nemzeti Bank közgazdasági elemzője. E-mail: boldizsara@mnb.hu Kocsis Zalán a Magyar Nemzeti Bank vezető közgazdasági elemzője. E-mail: kocsisz@mnb.hu Nagy-Kékesi Zsuzsa a Magyar Nemzeti Bank vezető közgazdasági elemzője. E-mail: kekesizs@mnb.hu Sztanó Gábor a Magyar Nemzeti Bank elemzője. E-mail: sztanog@mnb.hu

Köszönettel tartozunk Balogh Csabának, Koroknai Péternek hasznos észrevételeikért a tanulmány és az azt megelőző elemzések készítésénél, a tanulmányunkban használt adatok lekérdezéséért, illetve az adatokkal kapcsolatos szakértői támogatásért Kürtösi Attilának, Némethné Székely Edinának és Brinzik Bélának. Ezúton szeretnénk megköszönni, hogy az áprilisi interjúkban valamennyi megkeresett belföldi bank Treasury/ALM kollégái készségesen segítették munkánkat, és tudásukkal hozzájárultak a piac jobb megértéséhez.

A magyar nyelvű kézirat első változata 2020. június 17-én érkezett szerkesztőségünkbe.

DOI: http://doi.org/10.25201/HSZ.19.3.551 
lemben, mert számos exportőr és importőr használja a határidős devizaügyleteket (forwardokat) az árfolyamkockázata mérséklésére. A kockázatkezelési lehetőség elősegítheti a külkereskedelmet és így a gazdasági aktivitást is. Elsősorban fedezeti céllal használják a hazai befektetési alapok is a határidős piacot, leginkább a devizaeszköz-portfólió árfolyamkockázatának mérséklésére. Emellett a szakirodalom által is körüljárt carry trade cél (a magasabb kamatozású devizában felvett pozíció) és az árfolyamvárakozásokat tükröző spekulatív cél is jelen van az ügyletkötések mögött. Utóbbi főként a lakossági ügyfélkör, valamint az exportőrök ügyleteinél érhető tetten. A belföldi szereplők általában a forint/euro árfolyam átlaghoz történő visszahúzására fogadnak.

A jegybank számára a határidős devizapiac azért is fontos, mert ez a piac historikusan támaszt nyújtott a forint azonnali piacának, és erősítette annak likviditását. A hazai devizát érő globális sokkokat - amelyek jellemzően külföldi szereplők vásárlásai vagy eladásai révén gyűrűznek be a piacra - a hazai szereplők ellentétes irányú határidős piaci múveletei tompítják, így kisebb elmozdulást tapasztalhatunk az árfolyamban ahhoz képest, mintha a belföldiek ilyen jellegű tevékenységet nem végeznének.

Elemzésünk aktualitását a 2020. március végi, koronavírus járvánnyal kapcsolatos pénzügyi piaci turbulencia adja, amely során a határidős piac a korábbiaktól eltérő mintázatot mutatott, a forintárfolyam volatilitásának csillapítása helyett felerősítette azt. Ennek hátterét banki interjúk és a Magyar Nemzeti Bank számára elérhető adatok alapján tártuk fel.

\subsection{Kapcsolódó szakirodalom}

Elemzésünk nagyobb része leíró jellegű, és célja leginkább a hazai határidős devizapiac alapvető jellemzőinek, szerkezetének bemutatása. Ezáltal a tanulmány folytatja azt a tradíciót, amit a Magyar Nemzeti Bank (MNB) átfogóbb, a hazai pénzügyi piacot - és ezen belül konkrétabban a devizaderivatíva-piacokat (Csávás - Gereben 2005; Csávás et al. 2006; Gereben et al. 2006; Csávás - Szabó 2010; Páles et al. 2010; Banai et al. 2013; Kocsis et al. 2013) bemutató tanulmányai képviselnek. Ebben a sorban legszorosabban a határidős devizapiaccal is részletesebben foglalkozó Csávás et al. (2006) tanulmányhoz kapcsolódunk. Ez a tanulmány már 2006ban felfedte a hazai határidős piac legmarkánsabb jellemzőit, beleértve a vállalati szektor kereskedési tevékenységének hátterében húzódó okokat. Jelen tanulmány nagymértékben épít ezekre a meglátásokra és megvizsgálja, hogy az elmúlt közel 15 évben ezek a jellemzők milyen irányba változtak.

A nemzetközi pénzügyi piacokkal kapcsolatos, hasonló motivációjú, leíró jellegű elemzéseket leginkább a Bank for International Settlements (BIS) publikál. Támaszkodunk a BIS Triennial Survey adataira (BIS 2019a), illetve az azt feldolgozó, leíró jellegű, de a globális devizapiaci folyamatok hátterét is elemző BIS-tanulmányokra 
(Borio et al. 2017; BIS 2019b). Borio et al. (2017) szerint a globális gazdaságot alapvetően formálja a mérlegben meg nem jelenő, derivatív tételeken keresztül szerzett finanszírozás: számításaik szerint 10,7 billió dollárnyi adósság bújik el így a mérlegekben. Hagyományosan a külkereskedelemben aktív vállalatok „természetes” devizakitettségének kezelésében volt meghatározó szerepe a forward-ügyleteknek, hiszen az exportőrök devizabevételüket, míg az importőrök devizakiadásaikat fedezik határidős devizaeladással és -vásárlással. Ugyanakkor a BIS tanulmányai (Borio et al. 2017; Patel - Xia 2019) szerint a pénzügyi vállalatok és bankok közötti (inter-dealer) tranzakciók a nem pénzügyi vállalati derivatíváknál lényegesen nagyobb volument tesznek ki, és az utóbbi időkben a piac növekedését is leginkább a pénzügyi befektetésekhez kapcsolódó tranzakciók alapozták meg.

Tanulmányunk kapcsolódik ahhoz a kiterjedt szakirodalmi szegmenshez, amely a (nem pénzügyi) vállalati szektor devizapiaci tevékenységét (elsősorban devizahitel-felvételt és határidős deviza ügyletkötéseket) tárgyalja. Ennek a szakirodalmi ágnak az egyik - továbbra is inkább leíró jellegű - elemzési területe a természetes devizakitettség számszerűsítése és annak felmérése, hogy a vállalatok milyen módon és mértékben fedezik ügyleteiket, és hogy milyen különbségek vannak e tekintetben különböző cégek között. Geyer-Klingeberg et al. (2019) nagyszabású szakirodalmi metaanalízise (a szakirodalom terjedelmére utal, hogy 175 tanulmány eredményeit vetik össze) bemutatja, hogy az eredmények nagyban függnek a választott módszertől és a (nemzetközi és időbeli) mintától.

Általánosnak tűnő konklúziók ugyanakkor, hogy a nagyobb méretű és nemzetközileg jobban integrált vállalatok, amelyeknek nagyobb a természetes devizakitettsége (multinacionális cégek) nagyobb arányban és volumenben aktívak a fedezési múveletekben (pl. Guay - Kothari 2003; Kim - Sung 2005; Geyer-Klingeberg et al. 2019). A hazai vállalati szektorral kapcsolatban Bodnár (2009) is hasonló eredményre jut. Nemzetközi összevetések megerősítik, hogy szignifikáns különbségek vannak országok között egyrészt a pénzügyi piacok általános fejlettségi különbségei miatt (Pramborg 2005), másrészt azért, mert a válságnak jobban kitett, dollarizált országokban nagyobb a természetes fedezetre vonatkozó igény (Gatopoulos - Loubergé 2013).

A vállalatok határidős piaci részvételével (és devizaadósság bevonásával) kapcsolatos másik központi kérdés az, hogy (a fedezési motiváción felül) milyen más indoka lehet a vállalati szektor fedezeti múveleteinek. A korai kockázatmenedzsment-szakirodalom a vállalati természetes cash-flow fedezési motiváción túl a menedzsment saját kockázatainak, jövedelmi kitettségének szempontjait említi (pl. Smith - Stulz 1985), illetve a spekulatív célú ügyletkötéseket (Géczy et al. 2007) emeli ki. A spekulatív célú ügyletkötések alatt a szakirodalom leginkább a fedezetlen kamatparitás empirikus nemteljesülésével, a forward premium rejtéllyel (Fama 1984; Yu 2013; Barroso - Santa-Clara 2015; Jurek 2014) kapcsolatos carry trade stratégiát érti, amely 
során a piaci szereplők a magasabb kamatozású deviza irányában tartanak nyitott devizapozíciót (alacsony kamatozású devizaforrásokból tartanak magas kamatozású devizaeszközöket). További kínálatoldali (a bankok forráskínálatából, a bankok saját devizakitettségének fedezéséből következő) motivációja is lehet a vállalatok devizapiaci vásárlásainak.

Hazai adatokon különböző szerzők különböző módszerekkel (Csávás et al. 2006; Bodnár 2006, 2009; Harasztosi - Kátay 2020) megerősítik a vállalatok fedezeti motivációjából következő ügyletkötéseket, bár Harasztosi - Kátay (2020) vállalati szintre bontott adatai az ügyletek kis részét köti fedezési motívumhoz. Harasztosi - Kátay (2020) elemzésében a kamatkülönbözet kihasználása sem volt jelentős, ami ellent mond Bodnár $(2006,2009)$ kérdőíves felmérésekben látott eredményeinek. Kim Chance (2018) érdekes módon a kérdőíves felmérésekben inkább nagyobb mértékű fedezési szándékot tapasztal a megvalósult, inkább spekulatív célú tevékenységhez képest. Csávás et al. (2006) a nem pénzügyi vállalatok forint árfolyamának stabilitásával kapcsolatos várakozásainak megfelelő kereskedési mintát figyelt meg. Vonnák (2018) és Harasztosi - Kátay (2020) a bankok kínálatoldali tevékenységének jelentős hatását emeli ki.

A vállalatok devizakitettségeinek fedezése vagy éppen a vállalatok mérleg szerinti pozíciójukkal kevésbé összefüggő spekulatív tevékenysége mikrooldalon a vállalatok értékének meghatározódásában (Allayannis et al. 2012) és hitelkockázatának megállapításában fontos, makroszinten pedig ez a kérdéskör a pénzügyi stabilitás témaköréhez vezet el. A vállalatok szisztematikus fedezetlen devizaadóssága pénzügyi stabilitási problémákhoz vezethet, és a reálgazdasági tevékenységre is érezhető negatív hatással lehet válság során (Endrész et al. 2012; Endrész - Harasztosi 2014; Endrész 2020).

Végül, a pénzügyi szektor szereplőinek kockázatkezelésével foglalkozó szakirodalom is releváns tanulmányunk szempontjából. Ez az irodalom különböző eszközosztályok/ árfolyamok közötti empirikus összefüggések alapján vizsgálja, hogy a nemzetközi portfólióval rendelkező befektetők esetében a kockázatkezelési stratégiák, és így a devizaderivatívák használata milyen tulajdonságokkal rendelkezik (pl. Massa et al. 2016; Mun 2016).

\subsection{Adatforrások}

A hazai határidős devizapiacról a jegybank által szervezett két banki adatszolgáltatásra támaszkodunk. A D01-jelentésben az MNB 1999 óta kér be napi szintű devizapiaci tranzakciós adatokat a belföldi hitelintézetektől. Ebből az adatszolgáltatásból nyomon tudjuk követni a hazai bankok által kötött azonnali, határidős (forward és futures), opciós és deviza-swap-piaci múveleteket. A bankok minden tranzakciónál jelentik az ügylet vételi és eladási devizanemét és volumenét (ez alapján az árazást), 
kötési és - ahol releváns - lejárati dátumokat, a partner jellemzőit (belföldi/külföldi rezidencia, banki/nem banki szereplő, pénzügyi szereplők esetében általában konkrét azonosítót is), valamint egyéb ügyletjellemzőket (tőzsdei/OTC kereskedés, letéti fedezet kapcsolódik-e, azonnali ügyleteknél derivatív ügyletek leszállításához kötődik-e a tranzakció) és árazási paramétereket (opcióknál opciós díjat, kamatozó devizacserénél releváns kamatozást). A D01-jelentés fontos előnye az idősor historikus mélysége, napi frekvenciája, illetve a piac napi monitoringját lehetővé tevő gyors adatközlés (a tranzakciókat a kötéseket követő napon jelentik).

Másik adatforrásunk a 2017-től elérhető, havi frekvenciájú M05 jelentésből származik, amit ugyancsak a hitelintézetek szolgáltatnak a jegybanknak a hónap végén kint lévő deviza- és kamatderivatíva-állományaikról. A határidős devizaügyletek esetében a bankok minden nyitott devizapárra (mindkét irányban), azon belül nagyobb lejárati kategóriákra (éven belül, 1-2 év közötti, 2 éven túli) közlik az állomány névértékét és piaci értékét, az adott időszaki ügyletkötési volument (darabszámot). Az M05 adatforrás egyik legfontosabb előnye számunkra, hogy a banki határidős devizapiaci állományokat a partnerek szektora szerinti bontásban közlik, és ebból óvatosan következtethetünk a belföldi pénzügyi és nem pénzügyi szereplők (azon belül külön a lakosság és a vállalatok) határidős állományaira és nettó kitettségére. A D01 jelentésben szereplő partnerkódok és rezidenciakód is segítenek a partnerek elhelyezésében, de itt sok a hiányzó vagy technikai jellegű azonosító, emiatt az M05 jelentés a szektorális összetételt sokkal pontosabban ragadja meg.

A két adatforrás mellett anekdotikus információkat gyűjtöttünk a határidős piacról. Összesen nyolc nagyobb hazai bank Treasury/ALM munkatársaival készítettünk interjút április elején. Ez a nyolc bank a hazai bankrendszer kint lévő határidős devizaállományának 85 százalékát fedi le.

A tanulmányhoz használt további adatforrások a BIS által gyújtött nemzetközi devizapiaci statisztikák, illetve az F07 jelú MNB-s adatszolgáltatás, ami 2009 óta a befektetési alapok főbb mérlegtételeiről tartalmaz havi szinten (forint, euro és egyéb deviza bontásban) információt.

\subsection{A tanulmány felépítése}

A tanulmány következő fejezete a határidős devizapiac leíró jellemzését tartalmazza, azonosítva a nemzetközi devizapiacon belül azt a részpiacot, amire a tanulmány koncentrál, tehát a forint relációjában kötött, azon határidős ügyleteket, amelyeknek egyik partnere hazai bank. A fejezet ezután ennek a szegmensnek több deskriptív jellemzőjével (devizadenomináció, futamidő, ügyletméret) foglalkozik. A harmadik fejezet a hazai piac szerkezetét mutatja be, tárgyalva a három fontosabb szereplő (hazai bank, külkereskedelemben aktív vállalatok, befektetési alapok) fóbb részvételi motivációit. A negyedik fejezet a határidős állományok árfolyam-érzékenységének 
időbeli alakulásával foglalkozik, erre ad becslést. Az ötödik fejezet az idei tavaszi koronavírus-válsággal kapcsolatos időszak fejleményeit elemzi. A hatodik fejezet összegzi a tanulmány megállapításait.

\section{A határidős devizapiac általános jellemzői}

\subsection{Globális devizapiac}

A BIS Triennial survey ${ }^{1}$ alapján a globális devizapiaci forgalom, egy-két rövidebb megtorpanást leszámítva, trendszerűen emelkedett az elmúlt húsz évben (BIS 2019a). A 2016-os átmeneti megtorpanást Schrimpf-Sushko (2019) a globális devizapiacot megrázó 2015. januári svájci frank küszöb eltörléséhez és új szabályozási sztenderdekhez való alkalmazkodáshoz köti. A dinamikában (és a teljes forgalomban) érdekes módon a legfontosabb ügylettípust nem az azonnali (spot) ügyletek, hanem a devizacsere (devizaswap) -ügyletek jelentik. A devizacsere-ügyletek mellett azonban valamennyi deviza részpiac, így az azonnali, határidős és opciós piacok is érdemben bővültek. A BIS adataiból kiderül, hogy a piaci résztvevők között továbbra is meghatározó szerepe van a bankok pénzügyi piaci ügyfélkörének, amely 2019re a forgalom közel felét tette ki, míg a nem pénzügyi vállalatok tevékenysége 10 százalék alatt volt.

Az elemzésünk központjában álló határidős ügyletek a globális devizapiaci forgalom nagyjából 18 százalékát teszik ki. A forward-ügyletek részaránya jelentősen növekedett a 2000-es évekre jellemző 11-12 százalékkal szemben. A deviza-swapok (melyek az éven belüli FX-swap-ügyleteket és az éven túli kamatozó devizacsere-ügyleteket jelentik) ugyanakkor a 2010-es évek első felében kissé háttérbe szorultak, majd a 2019-es felmérésnél emelkedett ismét a részarányuk 50 százalék körülire a teljes devizapiaci forgalmon belül (1. ábra).

\footnotetext{
${ }^{1}$ Az FX-piac globális folyamatairól a BIS háromévente készített széleskörű felmérése, a BIS Triennial Survey a legkézenfekvőbb forrás. A BIS a felmérést a központi bankok koordinációjával készíti, a legutóbbi kiadáshoz 53 ország mintegy 1300 pénzintézete járult hozzá (BIS 2019a). A Triennial Survey az állományokról és a forgalomról (a publikáció évének április havi átlagos napi forgalmáról) közöl adatokat.
} 


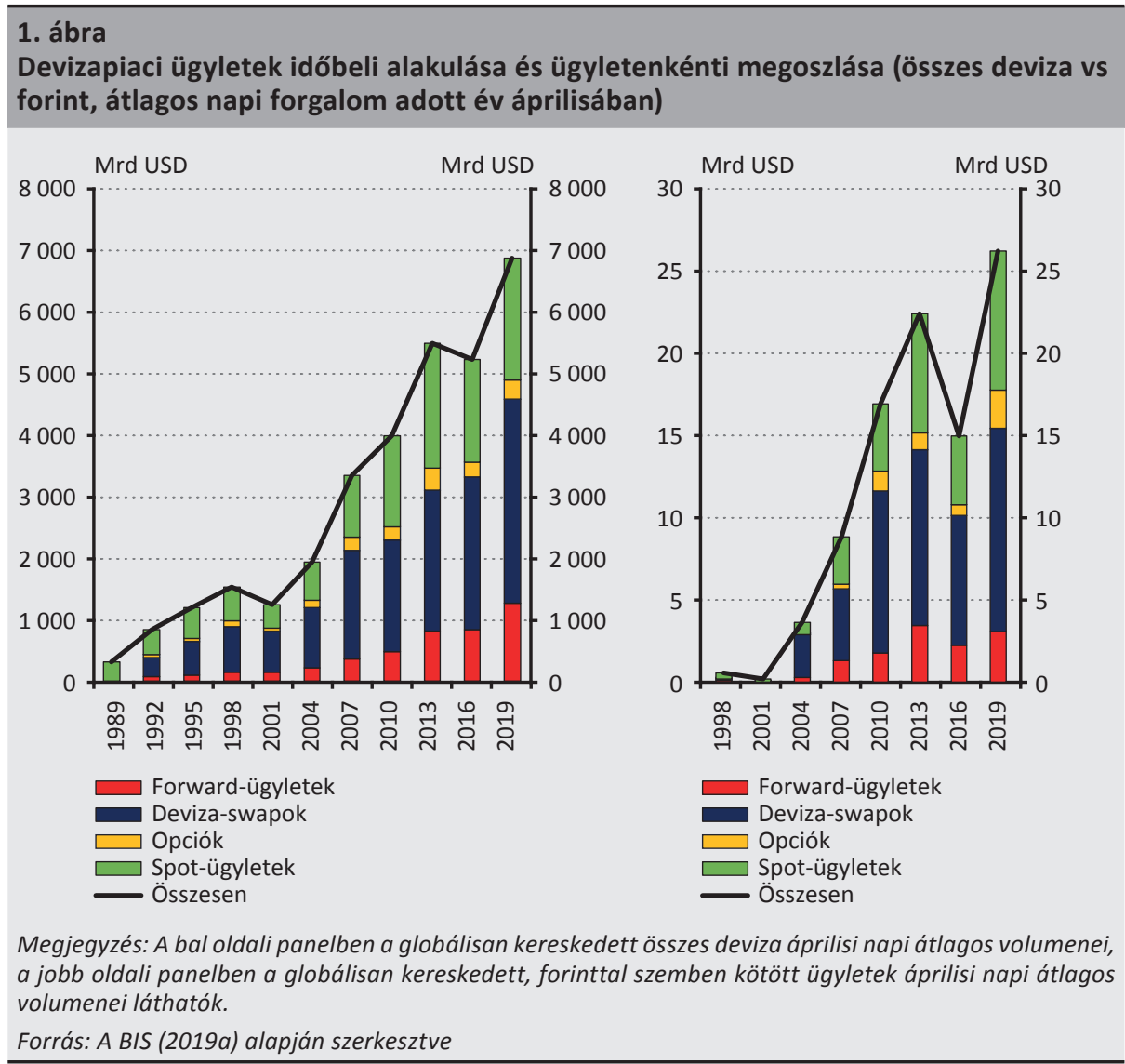

A forintpiac a globális devizapiac kis hányadát teszi ki. A globálisan megkötött devizaügyletek alig fél százaléka olyan, melyben a vételi vagy eladási denomináció forint. A globális vs forint relációjára a határidős ügyletek esetében is ugyanez mondható el.

A forint 2001-es konvertibilitásának megteremtése előtt a nemzetközi forintforgalom a jelenlegi volumenekhez képest jelentéktelen volt, majd a 2000-es évek elejétől különösen a devizacsere ügyletek ugrásszerű növekedése volt megfigyelhető. Hasonlóan az összes deviza szerint aggregált adatokhoz, a forintkereskedés is átmenetileg megtorpant 2016-ban. Ügylettípusok közül továbbra is a deviza-swapok teszik ki a volumen legnagyobb részét, stabilan a teljes piaci forgalom felét. Ezzel szemben a forwardok részesedése a forint ügyleteken belül csökkent: a 2013-ban és 2016ban tapasztalt 15 százalékhoz képest legutóbb 11 százalék volt. ${ }^{2}$

\footnotetext{
${ }^{2}$ A határidős pozíciók a gyakorlatban lényegesen nagyobbak lehetnek a megfigyelt határidős ügyletkötéseknél, ha figyelembe vesszük, hogy deviza-swapok és spotügyletek együttes alkalmazása esetén (szintetikus) határidős pozíció keletkezik.
} 
Mind a hazai, mind a BIS globális adatgyújtésében az euróval szemben kötötték a legtöbb forintügyletet. Ugyanakkor a BIS adatai alapján az euro részaránya megközelítőleg egyharmadra tehető, míg az MNB adatgyűjtése szerint nagyjából az ügyletek kétharmadában az euróval szemben kereskedik a forint. Ennek oka, hogy valószínúleg a nem-rezidensek közötti forintforgalom nagyobb arányban történhet dollárban, mint a hazai bankok által jelentett ügyletek esetében, melyet jellemzően euro érintettségű partnerekkel vagy partnerek nevében hajtanak végre. A nagyjából 3 milliárd dolláros napi forint forward-forgalomból a BIS szerint kb. 1 milliárd euróval szembeni, 2 milliárd pedig más devizával szembeni. A nem konszolidált adatok ugyanakkor arra utalnak, hogy az eurón kívüli ügyletek mellett a dollárral szembeni forintügyletek jelentősek (2. ábra).

\section{2. ábra \\ Forintügyletek megoszlása ügylettípus és forinttal szemben kötött devizák szerint}

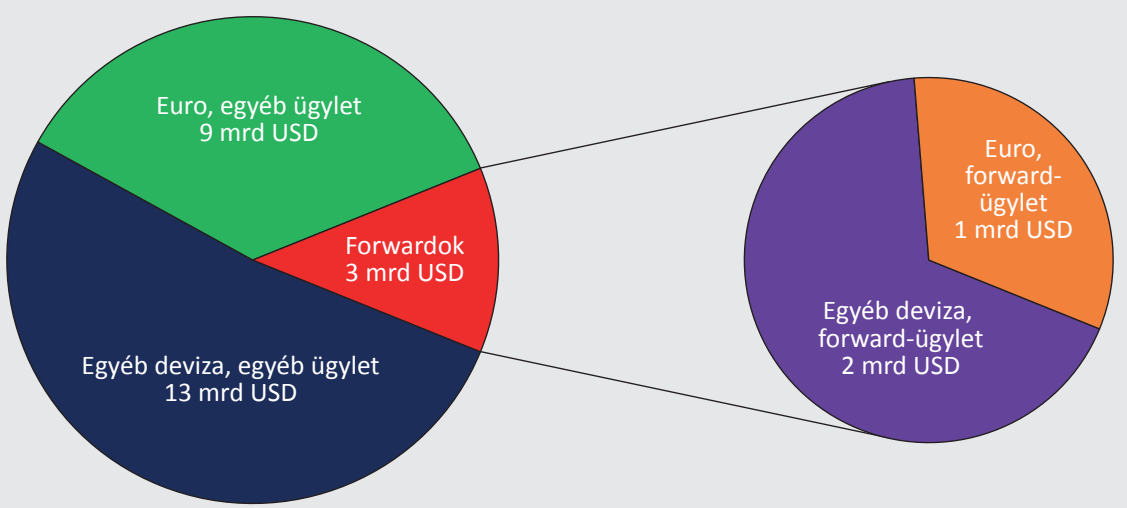

Megjegyzés: A baloldali diagram a globális forintügyletek forgalmának eloszlását mutatja be forwardok és más ügyletek (spot, swap, opció) szerint. A jobboldali diagram a globális forint forward-ügyleteket bontja tovább devizanem szerint.

Forrás: A BIS (2019a) alapján szerkesztve

A BIS adatai alapján a forintügyletek leginkább az Egyesült Királyságban és az Egyesült Államokban kerülnek megkötésre (BIS 2019a). A forintügyleteket jelentő piaci szereplők rezidenciája alapján nincs nagy átrendeződés az elmúlt években, továbbra is Magyarországon kívül kötik a legtöbb forintügyletet. Érdekesség, hogy az Amerikában kötött ügyletek aránya 2016 és 2019 között pont a forward-ügyletek esetében jelentősen csökkent, valamint néhány ázsiai pénzügyi központ is jelentett forintügyletet 2019-ben (Hongkong, Szingapúr, Kína). Amerikán és az Egyesült Királyságon kívül ugyanakkor nagyrészt Európában kötnek forintügyleteket, jellemzően olyan országokban, amelyeknek közvetlen kitettségük van a magyar pénzügyi piacokon. A belföldön kötött ügyletek aránya a felmérés szerint minden devizaügyletet figyelembe véve nagyjából 8 százalékos (3. ábra). 


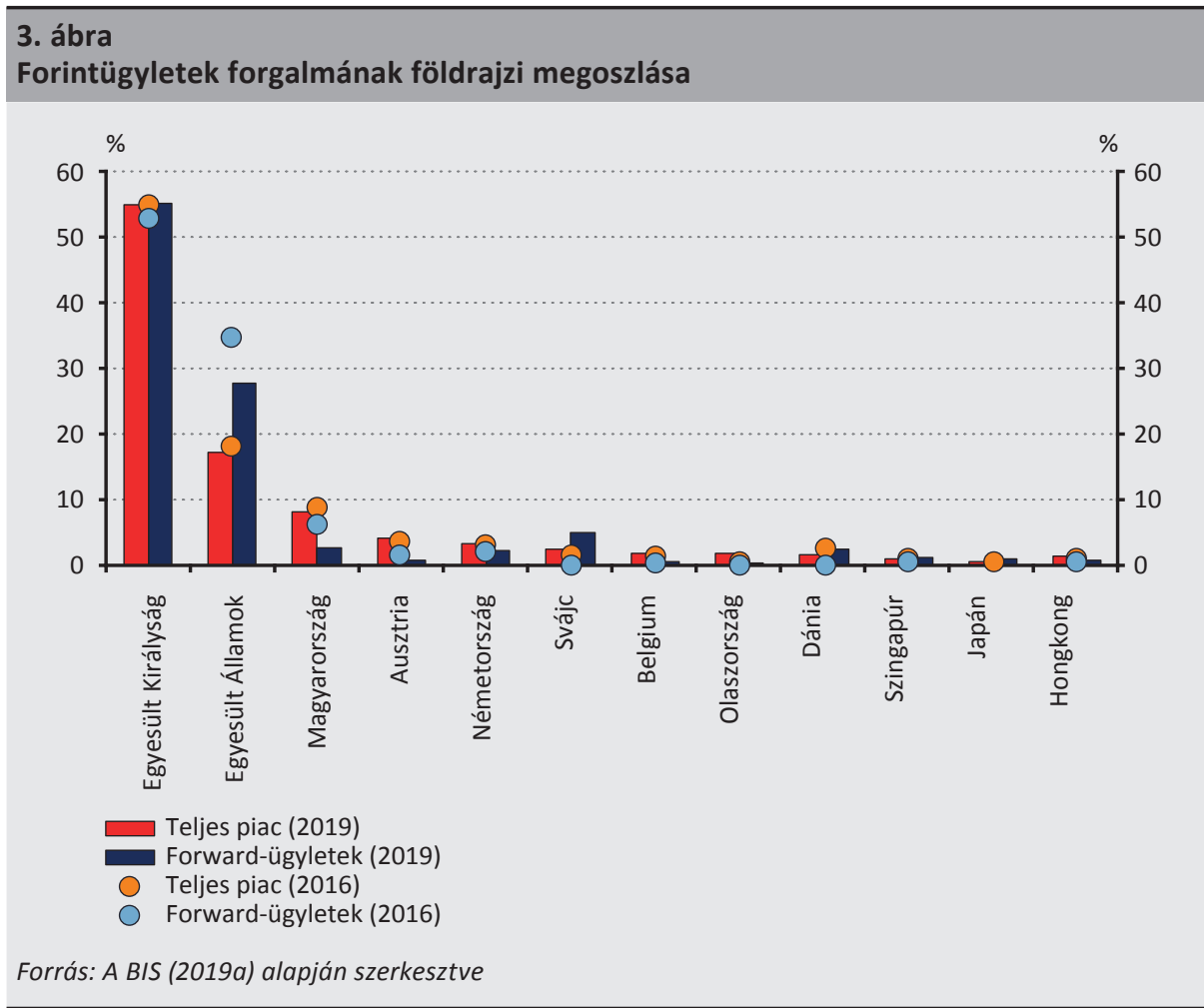

\subsection{A hazai devizapiac és határidős piac jellemzői}

Az MNB adatszolgáltatásai alapján megfigyelhető szegmens, a magyarországi forint/ devizapiac mérete az előzőekben bemutatott globális forintpiacnál jóval kisebb. A bankok által jelentett teljes devizapiaci forgalom nagyjából napi 900 milliárd forintot tesz ki, amiből a legnagyobb részt az FX-swap- és spot-tranzakciók teszik ki. A hazai forward-piac átlagos forgalma napi 65 milliárd forint, ami nagyjából konzisztens a BIS által gyűjtött adatokkal: a teljes globális forintpiac 6-8 százalékát teheti ki az MNB jelentéseiben nyomon követhető forgalom.

A magyar bankok által jelentett ügyletek alapján a forward-piacon leginkább a rövid szegmensben aktívak a piaci szereplők: az átlagos napi ügyletkötés közel háromnegyede legfeljebb 3 hónapos ügyletet takar, míg az éven túli ügyletek aránya alig másfél százalék. Ez összhangban van a BIS adataival is: a nemzetközi piacon a 3 hónapnál rövidebb ügyletek aránya 85 százalék, és csak az ügyletek mintegy 5 százaléka volt fél évnél hosszabb. 
A rövidebb futamidőkön nagyobbak az ügyletméretek is. Az 1-3 hónapos szegmens tartalmazza a legnagyobb átlagos ügyletenkénti volumeneket. Az ügyletméretek eloszlása pozitív ferdeségű: az átlagot kevés számú nagy tranzakció húzza felfelé, a tipikus ügyletek lényegesen kisebbek az átlagnál. A medián ügyletméret 30-60 millió forint körüli volt az átlagos 150-300 millió forinttal szemben (1. táblázat).

\begin{tabular}{|c|c|c|c|c|c|}
\hline \multicolumn{6}{|c|}{$\begin{array}{l}\text { 1. táblázat } \\
\text { Napi átlagos ügyletméret és forgalom }\end{array}$} \\
\hline & \multicolumn{5}{|c|}{ futamidő } \\
\hline & < 1hó & 1-3 hó & 3-6 hó & 6-12 hó & $>12$ hó \\
\hline átlagos napi forgalom (milliárd forint) & 30,0 & 20,9 & 8,1 & 5,6 & 1,1 \\
\hline \multicolumn{6}{|l|}{ ügyletméret (millió forint) } \\
\hline átlag & 269,1 & 286,7 & 235,8 & 240,0 & 144,1 \\
\hline perc $10 \%$ & 6,1 & 10,0 & 9,4 & 7,9 & 4,2 \\
\hline perc 20\% & 10,2 & 18,5 & 16,2 & 15,6 & 8,1 \\
\hline perc 30\% & 17,9 & 30,5 & 25,7 & 19,5 & 16,1 \\
\hline perc $40 \%$ & 29,1 & 34,1 & 31,9 & 31,3 & 22,4 \\
\hline medián & 34,4 & 59,2 & 45,8 & 34,9 & 32,1 \\
\hline perc $60 \%$ & 61,9 & 85,8 & 65,5 & 60,4 & 39,0 \\
\hline perc $70 \%$ & 98,1 & 136,8 & 106,7 & 85,3 & 60,1 \\
\hline perc $80 \%$ & 186,0 & 235,4 & 166,9 & 156,0 & 82,8 \\
\hline perc 90\% & 428,0 & 545,0 & 391,4 & 336,1 & 162,4 \\
\hline \multicolumn{5}{|c|}{ Megjegyzés: 2017. január - 2020. május minta alapján. } & \\
\hline
\end{tabular}

Az ügyletkötések futamidő-szerkezetének alakulása (4. ábra) alapján a legrövidebb, 1 hónapon belüli lejáratok tartósan a legtöbbször kötött ügyletek voltak, 2011 óta azonban a napi megkötött ügyletek darabszáma valamelyest csökkent ebben a futamidő-kategóriában. Az 1-3 hónapos futamidő-csoportban trendszerű emelkedést láttunk az idősor kezdete óta. 


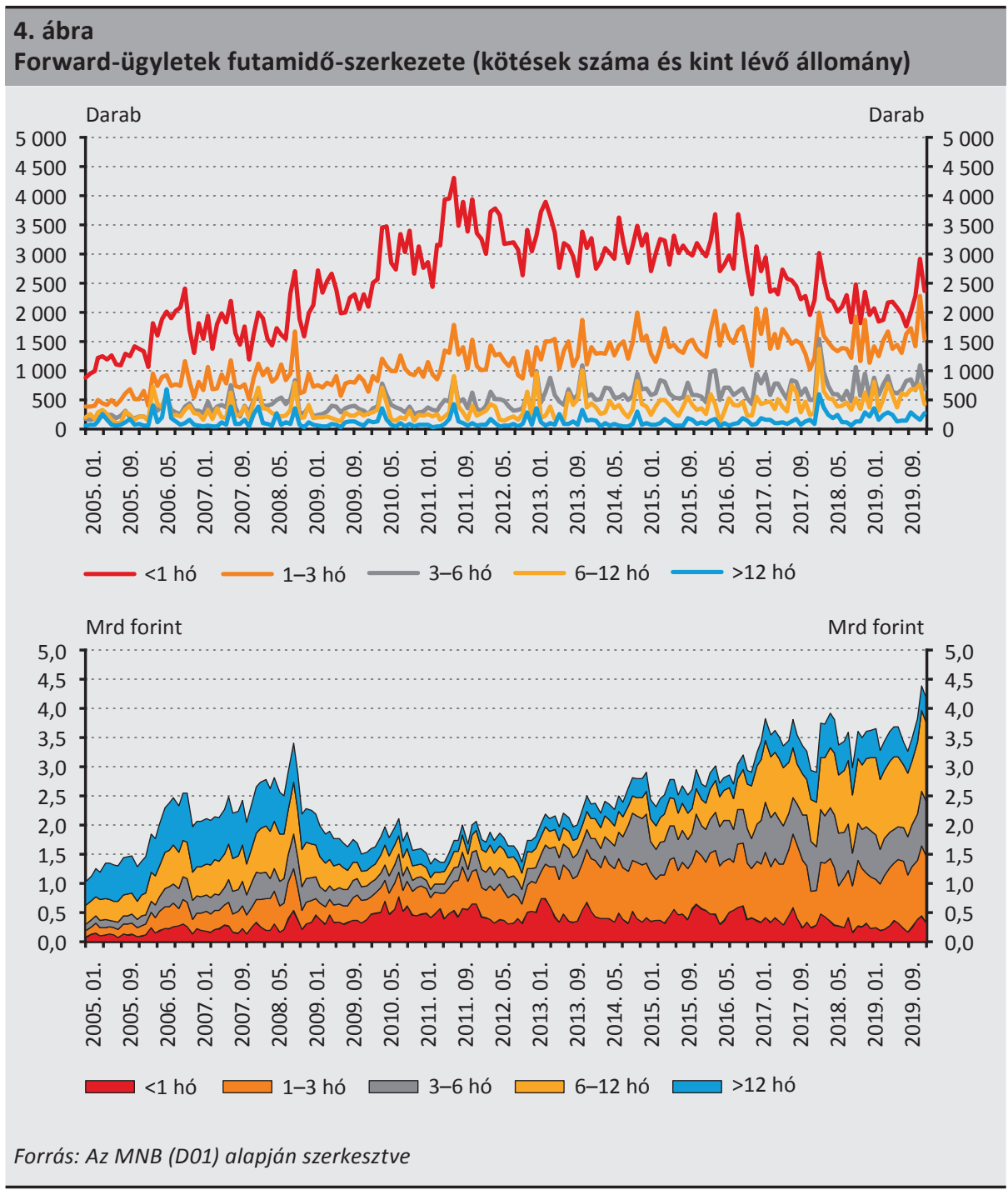

A tranzakciókhoz képest a kint lévő ügyletek futamidő-szerkezete más képet mutat. A fennálló állomány kétharmada 3 hónapnál hosszabb hátralévő futamidővel rendelkezik, míg a tranzakciók esetében ez az arány csak egynegyed körüli. A rövidebb futamidejü ügyleteket gyakrabban szükséges a szereplőknek megújítaniuk, ugyanakkor a hosszabb lejáratra kötött forwardok kisebb kötési volumenét ellensúlyozza ezen ügyletek hosszabb futamideje. Az állomány elmúlt években látott bővülése is sokkal inkább a hosszabb lejáratokhoz köthető. 


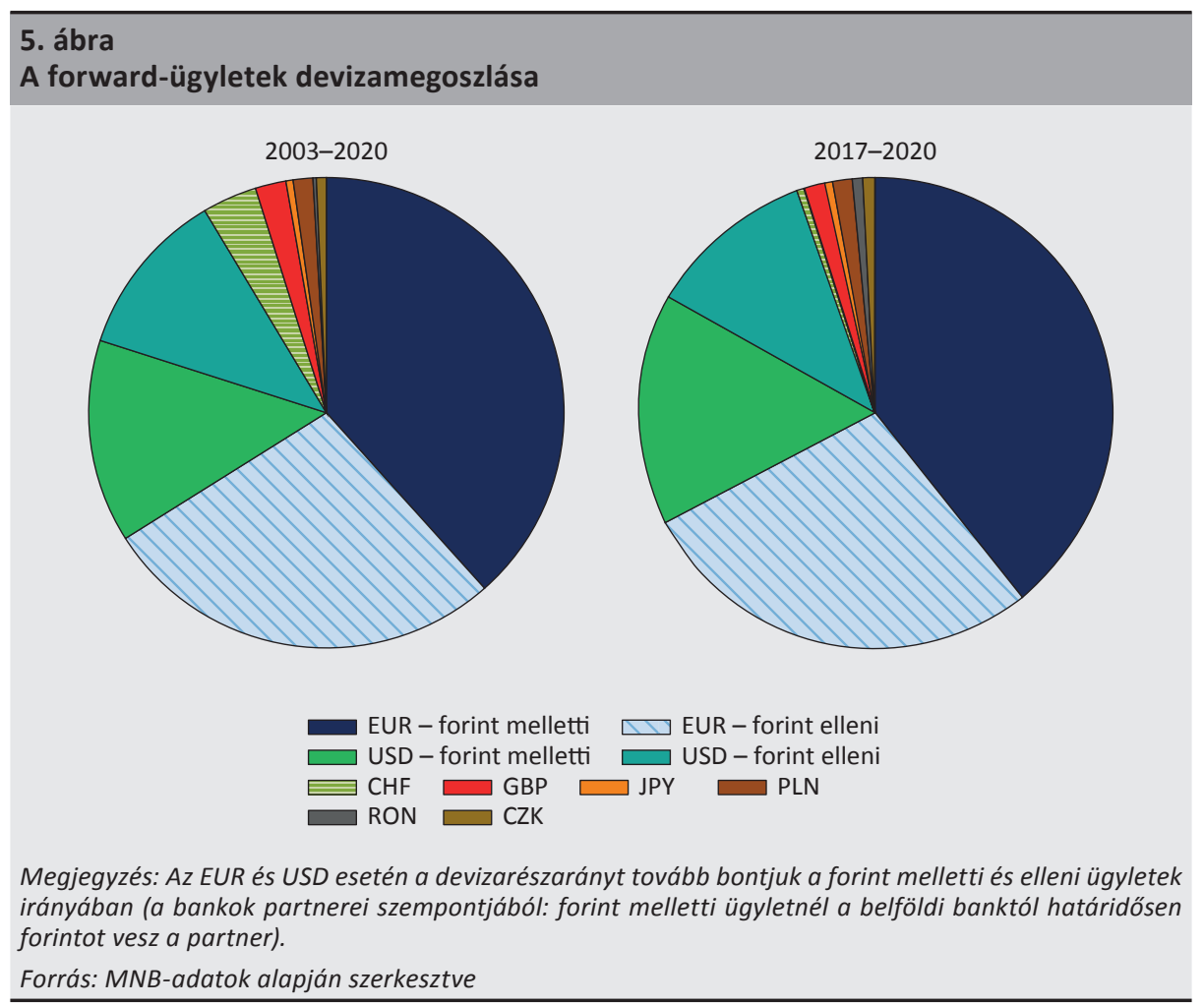

A devizabontást tekintve az látszik, hogy nincs jelentős változás az elmúlt években, továbbra is az euróval szembeni határidős ügyletek a meghatározók, ugyanakkor a BIS adatainál nagyobb mértékben, a magyarországi ügyletek közel kétharmadát euróval szemben kötötték a piaci szereplők (5. ábra).

\section{A hazai határidős devizapiac szereplői}

A havi rendszerességű M05 jelentésben a hazai bankok szektorok szerinti bontásban jelentik kint lévő derivatív-piaci állományaikat. ${ }^{3}$ Ezek alapján megállapítható, hogy a határidős devizapiacon a bankok ügyfélköre túlnyomórészt belföldi ügyfelekből állt, a külföldiek súlya alacsony volt (6. ábra).

A hazai pénzügyi szektor szereplői tették ki az állomány felét. Ezen a kategórián belül kifejezetten fajsúlyosak a befektetési alapok, és csak kisebb részt képviselnek a biztosítókkal, nyugdíjpénztárakkal, egyéb pénzügyi vállalatokkal és más hitelintézetekkel kötött ügyletek. Az állomány további közel 40 százalékát teszik ki a nem

\footnotetext{
${ }^{3}$ A napi, tranzakciószintű D01-ből a bankok pénzügyi szektorbeli partnereinek nagyrészét tudjuk azonosítani, de a (nem pénzügyi) vállalati, illetve lakossági ügyfeleket a jelentésben csak aggregáltan lehet nyomon követni.
} 
pénzügyi vállalatok. Erről a szektorról nincsenek vállalatonként elérhető azonosítók, így banki megkereséseink alapján tudjuk, hogy forward-ügyleteket elsősorban a külkereskedelemmel foglalkozó vállalatok kötnek, ezen belül is inkább az exportőr vállalatok meghatározók. Kisebb állományi részarányt tesznek ki a lakossággal és önkormányzatokkal kötött ügyletek. Érdekes módon a külföldi szereplők alig vannak jelen a piac hazai szegmensén. Ennek a háttere, hogy a nem-rezidensek közül, akik a hazai bankokkal ügyletet kötnek (globális bankok, anyabankok) azok jellemzően (szintetikus) forward pozíciót már inkább FX-swapok és spot-ügyletek kombinációja révén állítanak elő (az FX-swapok jellemzőiről és használatáról részletesen ír többek között Páles et al. 2010; Csávás - Szabó 2010).

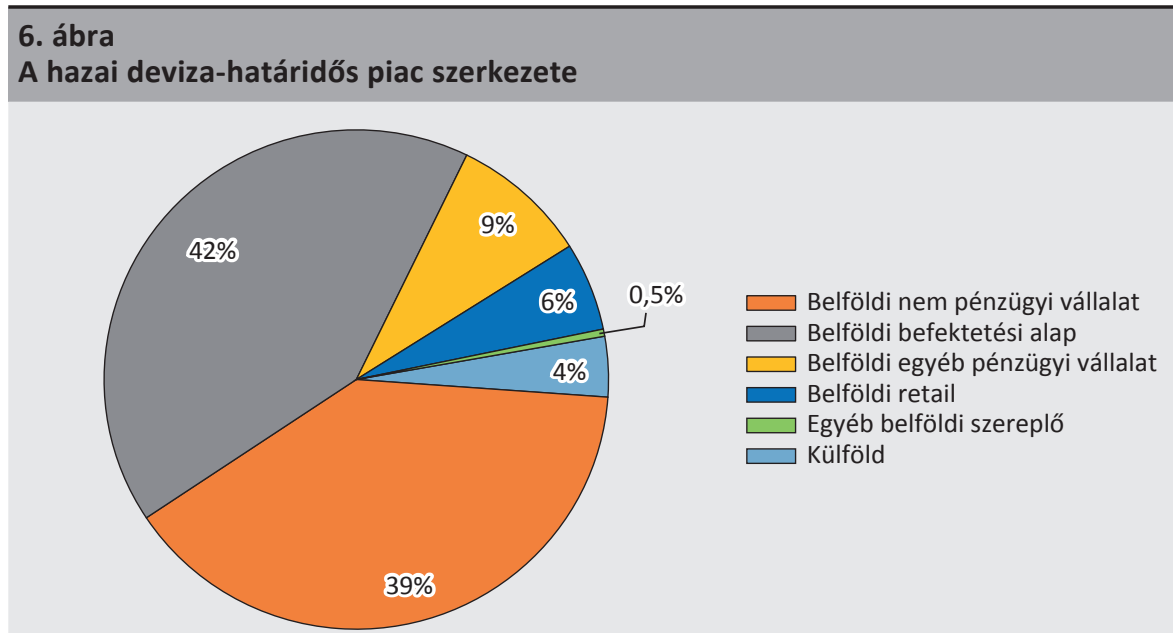

Megjegyzés: hazai adatszolgáltató bankok ügyfélköre a határidős devizapiacon (2020. március). Forrás: MNB (M05-ös jelentés)

Összességében elmondható, hogy a hazai határidős piacnak három meghatározó szereplőcsoportja van: a hazai befektetési alapok, a külkereskedelemmel foglalkozó vállalatok és a közvetítő hazai hitelintézetek. 2017 és 2020 között ez a szerkezet állandó volt, és a pontos részarányok is csak kismértékben változtak.

Ez a fejezet ennek a három szereplőnek a határidős devizapiaci tevékenységét mutatja be.

\subsection{Adatszolgáltató bankok}

A hazai bankok közvetítőként vesznek részt a határidős devizapiacon, valamint a devizapiac többi szegmensén. Egyfelöl határidős devizapozíciók egy deviza-swap és egy azonnali ügylet kombinációjaként is előállíthatók, így az ehhez képest vett félreárazások arbitrázslehetőséget jelentenek. Másrészt makroprudenciális szabá- 
lyozások miatt ${ }^{4}$ a bankok nem tartanak számottevő nyitott devizapozíciót (mérlegfőösszeg-arányosan a teljes nyitott devizapozíció fél százalék körül mozog), így a nem pénzügyi vállalatoktól és befektetési alapoktól érkező forward-keresletre a másik két piacon találnak ellenügyletet (és fordítva: a forward-piacot is használják a másik két piacon kötött ügyletek ellentételezésére).

Példaként az exportőr részéről érkező határidős forintvételi kereslet miatt a bank devizapozíciója a nettó devizaeszköz irányában nyílik, ennek fedezésére a bank (ellenirányú forward-ügylet mellett) az FX-swap-piacon bevont deviza azonnali értékesítésével teheti meg (7. ábra). Ekkor az FX swap termin $\left(T_{1}\right)$ lábán a banknak devizát kell visszafizetni, erre a forward-ügyletből származó devizát használhatja fel. Az árfolyam elmozdulásai ekkor a forward-ügylet és az FX-swap-ügylet értékét azonos mértékben, ellentétes előjellel mozgatják.

\section{7. ábra \\ Devizalikviditás áramlása forwarddal fedezett exportbevétel és fedezett banki devizapozíció esetén}

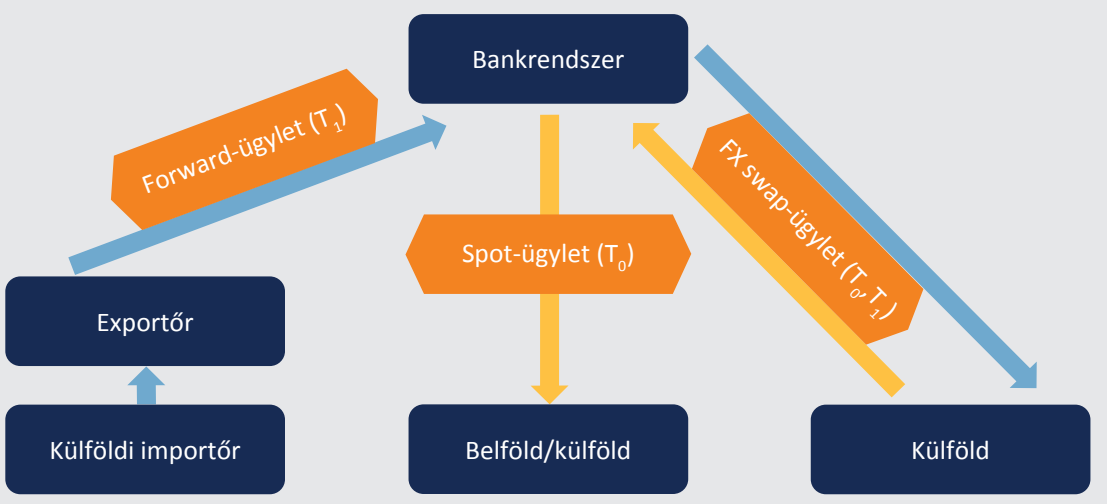

Megjegyzés: A sematikus ábra bemutatja a devizalikviditás áramlását az azonnali (sárga nyilak) és lejárati időpontokban (kék nyilak), amikor az exportör később esedékes devizabevételének árfolyamkockázatát forward-ügylettel fedezi, valamint a bankrendszer spot+FX swap (szintetikus forward) -ügylettel az exportör forward-ügylete miatt kinyíló devizapozícióját.

\subsubsection{Szektorális állományok a forint relációjában}

A hazai kereskedelmi bankok mindkét nagyobb ügyfélköre, a belföldi nem pénzügyi vállalatok és a belföldi befektetési alapok jellemzően forint melletti nettó pozíciót tartottak fent, tehát a határidőn forintvétellel és devizaeladással járó állományuk meghaladta a devizavételi-forinteladási állományt. Ezzel szemben tehát a hazai

\footnotetext{
${ }^{4}$ A devizafinanszírozás-megfelelési mutató (DMM) az egyes intézmények devizaeszközeihez igazodva várja el megfelelő mennyiségű stabil devizaforrás tartását. A devizaegyensúly-mutató (DEM) az eszközök és források közötti denominációs eltérés mértékét maximálja a mérlegfőösszeg arányában.
} 
bankrendszer vállalta a devizavételi nettó pozíciót és a spot-piacon, a külföldi szektorral szemben zárták a devizapozíciójukat.

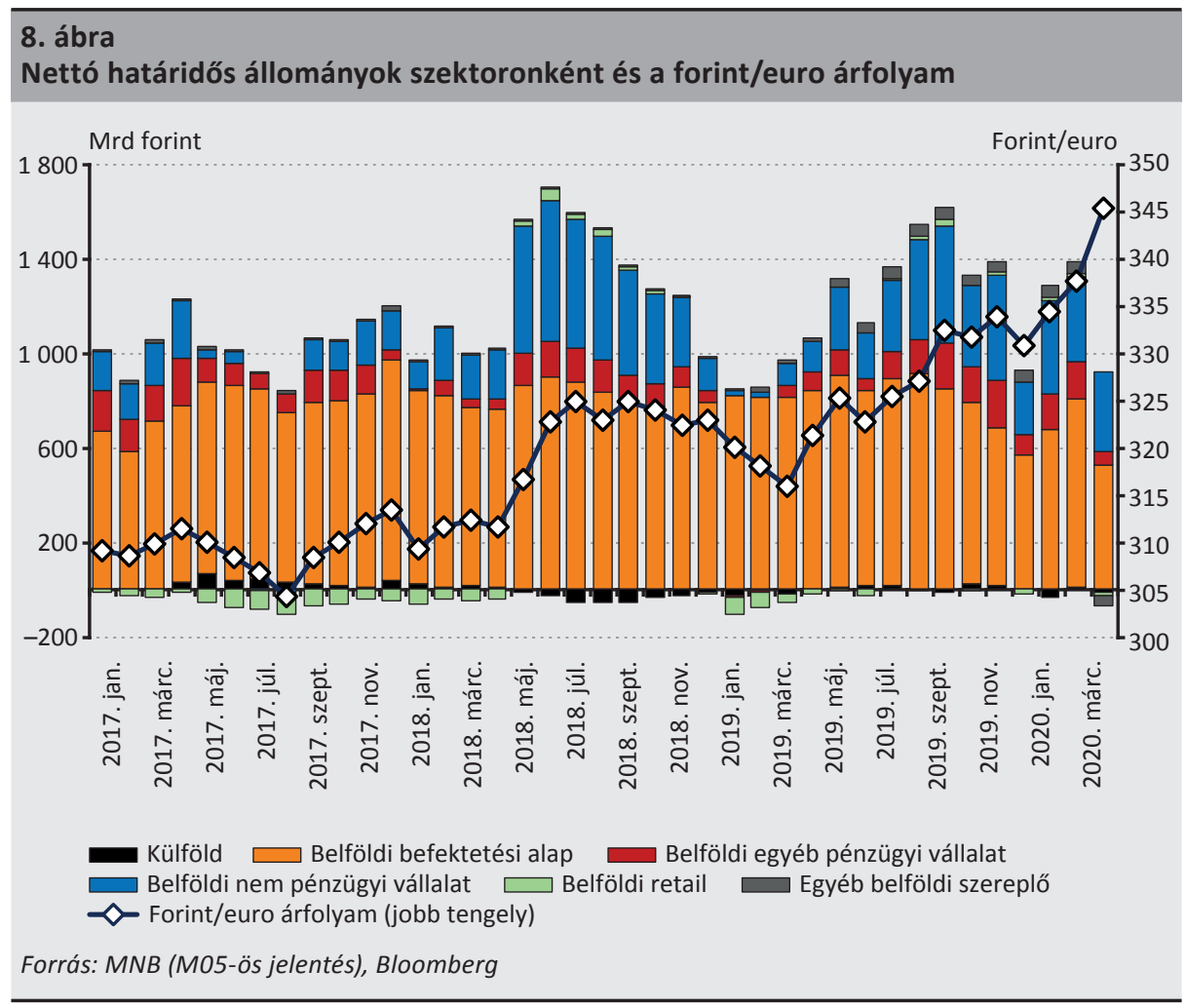

A belföldi pénzügyi és nem pénzügyi vállalatok bruttó forint melletti és forint elleni állományai hasonló dinamikát mutattak. A forint melletti oldalon 2017. tavasszal, 2018. áprilisban, 2019 második és harmadik negyedévében, valamint idén az év első két hónapjában tapasztaltunk jelentősebb állománynövekedést, amely hullámok eltérő amplitudóval ugyan, de mindkét szektornál jelen voltak. Ezek az időszakok egybeestek a forint leértékelődéseinek periódusaival, és egyben a nettó határidős pozíciókban is emelkedéseket okoztak (8. ábra).

A forint elleni ügyletekben 2017 közepén és 2018 legvégén volt egy-egy átmeneti állománymegemelkedés, valamint 2019 végén (a forint melletti állományemelkedéssel nagyjából párhuzamosan) tapasztaltuk a forint elleni pozíciók bővülését.

\subsubsection{Partnerkockázat kezelése: marginszámlák és pótfedezetek}

A hazai bankok tehát alacsony devizapiaci pozíciót tartanak, ugyanakkor kétoldali ügyletkötéseik révén jelentősebb partnerkockázattal szembesülnek. A forward-ügyletek értéke kötéskor közelítőleg nulla, mivel az ügylet épp a beárazott jövőbeli 
árfolyamot tartalmazza. Ugyanakkor az árfolyam későbbi elmozdulásai az ügylet értékét megváltoztatják, azonos mértékben, de ellentétes irányban a rövid és hosszú oldali szereplők szempontjából. Végül az ügylet lejáratakor az előre beárazotthoz képest az eltérést a negatív pozícióval rendelkező fél átutalja a nyereséges fél számára. Ez a lejáratkori utalás partnerkockázatot jelent a veszteséges fél nemfizetési kockázata miatt.

A partnerkockázat kezelésére többféle bevett gyakorlat van. A pénzügyi szereplőkkel és lakossági ügyfelekkel szemben a kereskedelmi bankok a forward-ügyletek értékét napi szinten nyilvántartják és a pozíció veszteségére az ügyféltől a bank likvid fedezetet kér be. Amennyiben a fedezetet nem kapja meg a bank, akkor az ügyletet egy ellenirányú kötéssel lezárja.

A vállalatokkal szemben a megkérdezett bankok többsége más eljárást választ. Itt a banki kockázatkezelés előzetesen felméri a vállalatok profilját, és ez alapján keretszerződésben rögzíti a forward-ügyletek limitjeit. Ezek a keretszerződések a természetes fedezettségnek megfelelő irányú és a jellemző (éves) árbevételekhez mérten valamelyest alacsonyabb pozíciók felvételét engedélyezik (exportőrök számára forint melletti, importőrök számára forint elleni pozíciót), és ez önmagában alacsonyan tartja a partnerkockázatot. Például, ha a forint gyengül, és ez a forint melletti pozíciókat veszteségessé teszi, akkor az exportőrök esetében ezzel párhuzamosan az exportértékesítésből várható devizabevétel forintértéke szintén növekszik. Így reális feltételezni, hogy a forward-ügylet veszteségét a vállalat ki tudja végül egyenlíteni, és ezért pótfedezetek bekérése és ügyletek automatikus lezárása is ritkán történik meg.

\subsubsection{Piaci koncentráció}

A hazai határidős piacon 15-25 pénzintézet vett részt az elmúlt 10 évben, és ezek közül 8-10 bank tekinthető igazán aktívnak. Az évek során a részt vevő bankok száma csökkent, de ez kisebb szereplők kiesését jelentette, így a piaci koncentráció mutatói keveset változtak.

A Herfindahl-Hirschmann-index, amely a piaci részesedés négyzeteit összegzi (és szorozza fel 10 000-rel) az időszak nagy részében 1 000-1 500-as értékek között ingadozott, ami alacsony-közepes koncentrációra enged következtetni. A három legnagyobb szereplő piaci részesedése 50-60 százalék között mozgott.

\subsection{Külkereskedelemben aktív vállalatok}

A nem pénzügyi vállalati szektoron belül - a megkeresett bankok egyöntetű elmondása alapján - elsősorban a külkereskedelemben aktív vállalatok játszanak szerepet a határidős devizapiacon. Ezen a szektoron belül is inkább az exportőrök voltak meghatározók, bár az importőrök relatív szerepe trendszerűen emelkedett az elmúlt évtizedben. Az exportőrök a trend ellenére még mindig nagyobb súlyt képviselnek 
a piacon, ami tükröződött a belföldi vállalati szektor konzisztensen pozitív (forint melletti) nettó forward-állományában.

Az exportőrök nagyobb, de relatív csökkenő szerepének a hátterében több tényező áll. Az exportőrök számára a határidős pozíciók felvételében a természetes devizakitettség fedezete mellett a visszaerősödésre vonatkozó spekuláció és a carry trade vonzereje egyaránt szerepet játszottak. Ezen tényezők vállalati megítélésével kapcsolatban több banki interjú alapján az elmúlt évek során érezhető változás volt megfigyelhető.

\subsubsection{Határidős pozíciók mint természetes fedezeti ügyletek}

A szakirodalom részletesen foglalkozik a külkereskedelemből adódó természetes devizapozíció fedezetével. Az exportőrök számára a bevételek a jövőben és jellemzően devizában rögzített áron folynak be, így a bevétel realizálásáig az árfolyam változása kockázatot jelent a mérlegre: a forint erősödése az árbevételt forintban csökkenti. Ezt a kockázatot határidős forint melletti ügylettel (határidőn forintvétel devizaeladás ellenében) lehet csökkenteni, mert a forint erősödése esetén ez a pozíció nyereséges, így ellensúlyozza az exportbevételnél adódó árfolyamveszteséget. Devizaforrások bevonása is hasonlóképp hat, a forint erősödése esetén a devizatartozások forintértéke (vagy flow-szemléletben a devizaforrásokra fizetett kamat forintértéke) csökken, ami nyereséget eredményez.

Hasonlóképp az importőrök esetében a jövőben jelentkező devizakiadások árfolyamkockázatát forint elleni (határidőn forinteladás, devizavétel) forward-ügylettel, vagy devizaeszközök mérlegre vételével tudják mérsékelni. Mivel a külkereskedelmi mérlegünk jellemzően többletet mutatott az elmúlt évtizedben, de az export előnye 2016 óta csökkent, ez önmagában is magyarázza az exportőrök nagyobb, de relatíve csökkenő fedezési motivációját.

A vállalati szektor export- és importtevékenységéből származó árfolyamkockázat fedezettségének (egy bevallottan tökéletlen) indikációja a külkereskedelmi volumenek és a mérlegen belüli devizaeszközök, devizaforrások, valamint derivatív állományok aránya (9. ábra). ${ }^{5}$

\footnotetext{
${ }^{5}$ Stock-szemléletben a fedezettséget alapvetően úgy lehetne mérni, hogy a vállalatok mérlegeiben az export/import forgalomba kerülő, de az értékesítésig még az árfolyamalakulás miatt átárazódó eszközöket (készleteket) vetnénk össze a mérlegen belüli pénzügyi és mérleg alatti derivatívatételek értékével. Egyrészt csak szektorális, nem vállalati szinten vannak adataink, és a bruttó export és import - vállalaton belül - már egymással szemben is természetes fedezést nyújtanak az árfolyamkockázat tekintetében (ez már önmagában csökkenti a szükséges pénzügyi fedezetet). A vállalaton belüli természetes fedezettség szerepének fontosságát az export relatíve magas importtartalma is alátámasztja: 2015-ben a (jelentős részben exportra termelő) feldolgozóipari vállalatok teljes folyó termelő felhasználásának 70 százalékát tette ki az import (MNB 2020b). Másrészt az átértékelődő állomány helyett az export/import forgalmat tudjuk megfigyelni. A kettő ugyan összefügg, de nagysága jelentősen eltérhet attól függően, hogy a forgalomba kerülő termékek hány hónapig jelentenek átértékelődő mérlegtételt. A szakirodalomban Borio et al. (2017) is hasonló metrikát használ.
} 
A határidős devizapiaci állományok az áruexport és áruimport (12 havi volumen) 2-7 százaléka között ingadozott, a 2008-2009-es válságot követően a külkereskedelem teljes volumenéhez képest lényegesen lecsökkent a vállalatok forward-állománya. Érdekes, hogy ez (legalábbis 2009-2012 között) a devizaeszközök és -források állományának relatív emelkedése mellett ment végbe.

\section{9. ábra \\ A vállalati szektor mérlegen belüli devizatételei és forward-állományai az áruexport és -import arányában}

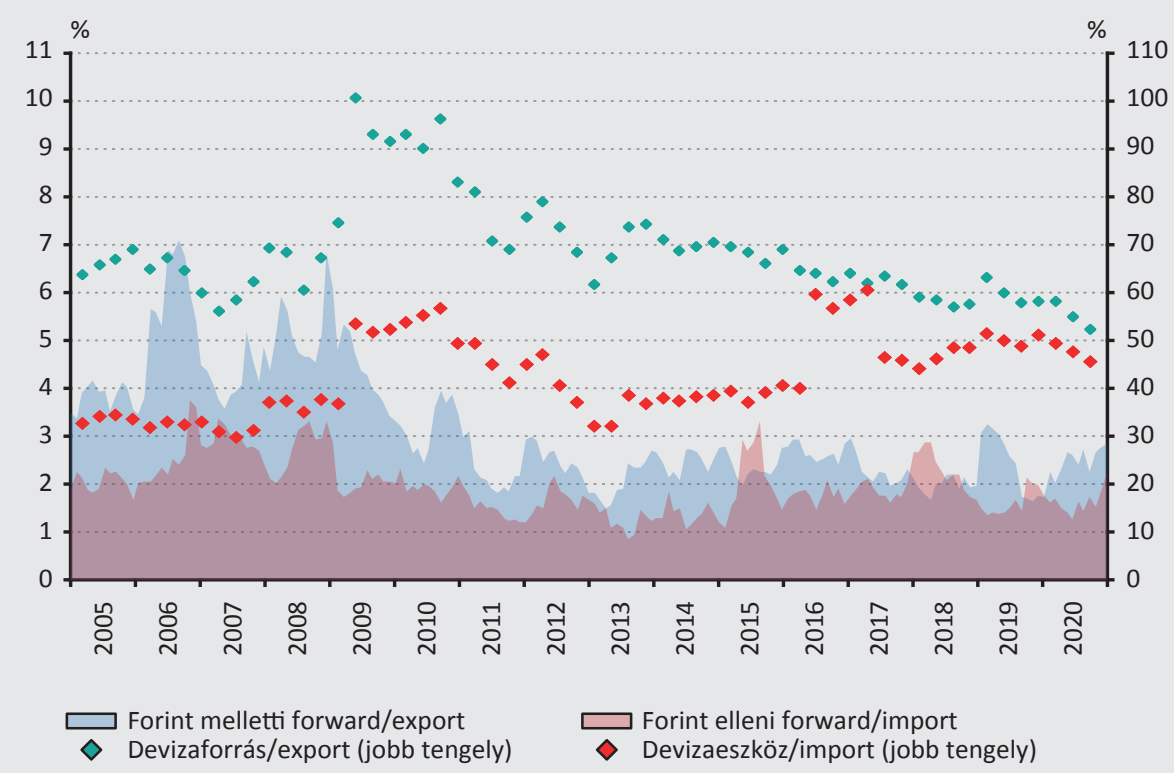

Megjegyzés: Nem pénzügyi vállalatok devizában denominált pénzügyi eszközei és forrásai, a D01-ben rezidens partnerként regisztrált ügyletek állományai az elmúlt 12 hónap áruexport és áruimport arányában.

Forrás: MNB (D01 jelentés, Fizetési mérleg statisztika)

A vállalatok devizaforrásai (devizahitelek, kibocsátott értékpapírok, devizatartozások) meghaladják a devizaeszközeiket (főként devizabetétek, értékpapírok), ami a nettó exportőr vállalati szektor számára összességében „természetes fedezettségükkel" konzisztens. Bruttó tekintetben a mérlegen belüli devizaeszközök és devizaforrások lényegesen meghaladják a határidős ügyletek állományát, így a devizakitettség jelentősebb részét fedezhetik a mérlegen belüli tételek. Mind a mérlegen belüli tételek, mind a derivatívák tekintetében elmondható, hogy azok nagyobbak voltak az export, mint az import arányában. 


\subsubsection{Határidős pozíciók spekulatív és carry trade tartalma}

A természetes devizapozícióik fedezése mellett egyszerűen tetten érhető a spekulatív, átlaghoz való visszahúzásra játszó eleme is az exportőrök határidős ügyleteinek, amit már Csávás et al. (2006) is bemutatott. A forint leértékelődéseinek az időszakaiban az exportőrök növelik a forint melletti pozíciókat, ahogyan ez 2020 tavaszát leszámítva általában is történt (8. ábra), mert ezekben az időszakokban a forint visszaerősödésére vonatkozó várakozások erősebbé válnak, ezért az exportőrök várt bevételeik nagyobb részarányát fedezik le. ${ }^{6} \mathrm{Ha}$ az exportőrök várakozásait nem jellemezné az átlaghoz visszatérés, akkor ez a mintázat nem lenne megfigyelhető. Több banki interjúalanyunk viszont az elmúlt években fokozatosan gyengülő forintárfolyamot olyan tényezőként említették, amely mérsékelte az exportőrök szerepvállalását, mert emiatt az újabb leértékelődések esetében kevésbé várták az exportőrök a forint visszaerősödését. Ugyanakkor ez a leértékelődés, ha befolyásolta a várakozásokat, akkor az importőrök oldalán is erősíthette a forint elleni pozíciók kiépítését.

Végül, a határidős forintárfolyam az azonnali árfolyamhoz képest jellemzően magasabb, mert be van árazva a kamatkülönbözet a forint és a külföldi deviza között. Ezt a fedezett kamatparitás reláció indokolja. ${ }^{7}$ Ahogy viszont a forintpénzpiaci hozamok az elmúlt évtizedben trendszerűen csökkentek, e különbözet nagy része az euro- és dollárpénzpiaci hozamokhoz képest elolvadt. Ebből következően míg korábban a határidős árfolyam lényegesen magasabb volt az azonnali árfolyamnál, tehát az exportőrök devizájukért magasabb forintösszeget kaptak a határidős piacon, mint az azonnalin, a kisebb kamatkülönbözet miatt ez a vonzerő az utóbbi években jelentősen mérséklődött. ${ }^{8}$ A csökkenő forintkamatok a forint határidős vételére vonatkozó kamatkülönbözeten alapuló, carry trade jellegű motivációt is számottevően csökkentette. Részben ez is hozzájárulhat a kamatkülönbözet fontosságával kapcsolatos régebbi (Bodnár 2006, 2009) és újabb (Harasztosi - Kátay 2020) szakirodalmi eredmények közötti eltéréshez.

\footnotetext{
${ }^{6} \mathrm{~A}$ banki interjúink is megerősítik az exportőröknek az árfolyamnak az átlaghoz való visszahúzására vonatkozó várakozásai által motivált kötéseit. Hüvelykujj-szabályként az egyik bank elmondása alapján a forwardpiacon aktív vállalatok exportbevételeik egyharmada és kétharmada között fedeznek határidős ügyletekkel. A részarány jellemzően akkor éri el a felső határt, amikor az árfolyam leértékelődik. A teljes fedezetet a vállalatok ugyanakkor nem szokták elérni egyrészt óvatossági megfontolásokból (nem kockáztatják a túlfedezettséget), de sokszor a banki keretszerződések limitjei is az alatt vannak meghatározva, és valószínúleg az ügyletek tranzakciós költségei miatt is inkább az alulfedezettség érheti meg.

${ }^{7} \mathrm{Ha}$ nem lenne a határidős árfolyam a kamatkülönbözettel magasabb az azonnali árfolyamnál, akkor arbitrázsmentes profitot lehetne elérni a magasabb kamatozású deviza tartásával.

${ }^{8}$ A fedezetlen kamatparitás elmélete alapján a magasabb kamatkülönbözet magasabb árfolyam-leértékelődési kockázattal jár. Ugyanakkor ennek teljesülése empirikusan vitatott, és a pénzügyi szakirodalom egyik nagy rejtélyét, a forward premium puzzle-t képezi (Fama 1984). E rejtély motiválja a (deviza) carry trade-et, amely alapján érdemes alacsonyan kamatozó devizából finanszírozni magasan kamatozó devizaeszközöket.
} 


\subsection{Befektetési alapok}

Banki interjúink alapján a befektetési alapok elsődleges részvételi motivációja a határidős devizapiacon portfóliójuk devizakockázatának részleges fedezése. A részleges fedezés összhangban áll a nemzetközi tapasztalatokkal. A Melvin - Prins (2015) által áttekintett referenciák alapján a nemzetközi részvényportfólióval rendelkező pénzügyi szektorbeli befektetők portfóliójuk árfolyamkockázatának felét, esetenként nagyobb részarányát fedezik le. Borio et al. (2017) alapján a nemzetközi részvénybefektetőknél 20-60, a nemzetközi kötvényportfóliók esetében 50-100 százalékos volt a megfigyelt fedezettségi arány.

A mérlegelemek árfolyamkockázatának részleges fedezése (a teljes fedezettséggel szemben) nem feltétlenül jelenti a spekulatív motiváció érvényesülését, következhet tisztán kockázatkezelési célokból is. A kisebb fedezettség következhet az árfolyamkockázat más kockázatokkal (pl. kamatkockázattal) való összefüggéséből is. A hozamok és árfolyam korrelációja eredményezheti azt, hogy már meglévő kamatderivatívák is részben fedezhetik a devizakitettséget (Mun 2016). Emellett a nagyobb árfolyamkitettségnek diverzifikációs előnyei is lehetnek nemzetközi részvénybefektetésekben (Massa et al. 2016). Au - Somefun (2018) továbbá kiemeli, hogy a részvényárfolyamok és devizaárfolyamok korrelációja miatt az árfolyam-fedezetlen nemzetközi részvénybefektetéseknek (MSCI World index alapján) 2008-2015 között kisebb volt a volatilitása, mint a fedezett indexnek. Ugyanakkor, mint látni fogjuk, a befektetési alapok nettó forward-állományai - a nem pénzügyi vállalatokéhoz hasonlóan - jellemzően emelkedett a forint leértékelődéseinek időszakaiban, ami inkább spekulatív motivációjú (az árfolyam stabilitására játszó) kereskedésre utal.

A hazai befektetési alapok forrásainak túlnyomó része forint befektetési jegyekből áll, amellyel szemben a nemzetközi befektetési portfólióval rendelkező alapok devizaeszközöket tartanak. A befektetési alapok portfólióösszetételében relatíve jelentős a devizaeszközök (részvények, devizakötvények és -betétek, valamint más befektetési jegyek) súlya. A devizaforrások súlya jellemzően kisebb a mérlegekben, így az alapokra pozitív nettó devizapozíció jellemző (10. ábra). A befektetési alapok megoszlását ilyen tekintetben a pozitív - semleges - negatív devizapozíciók 50-40-10 százalékos részarányai jellemzik.

A pozitív nettó devizakitettség (azoknál az alapoknál, amelyek ezt a kitettséget legalább részben fedezni akarják) forint melletti határidős devizapiaci részvételt indokol, és valóban, a befektetési alapok (a nem pénzügyi vállalatokhoz hasonlóan) szektorszinten jelentős forint melletti határidős állománnyal rendelkeznek ezen a piacon. 


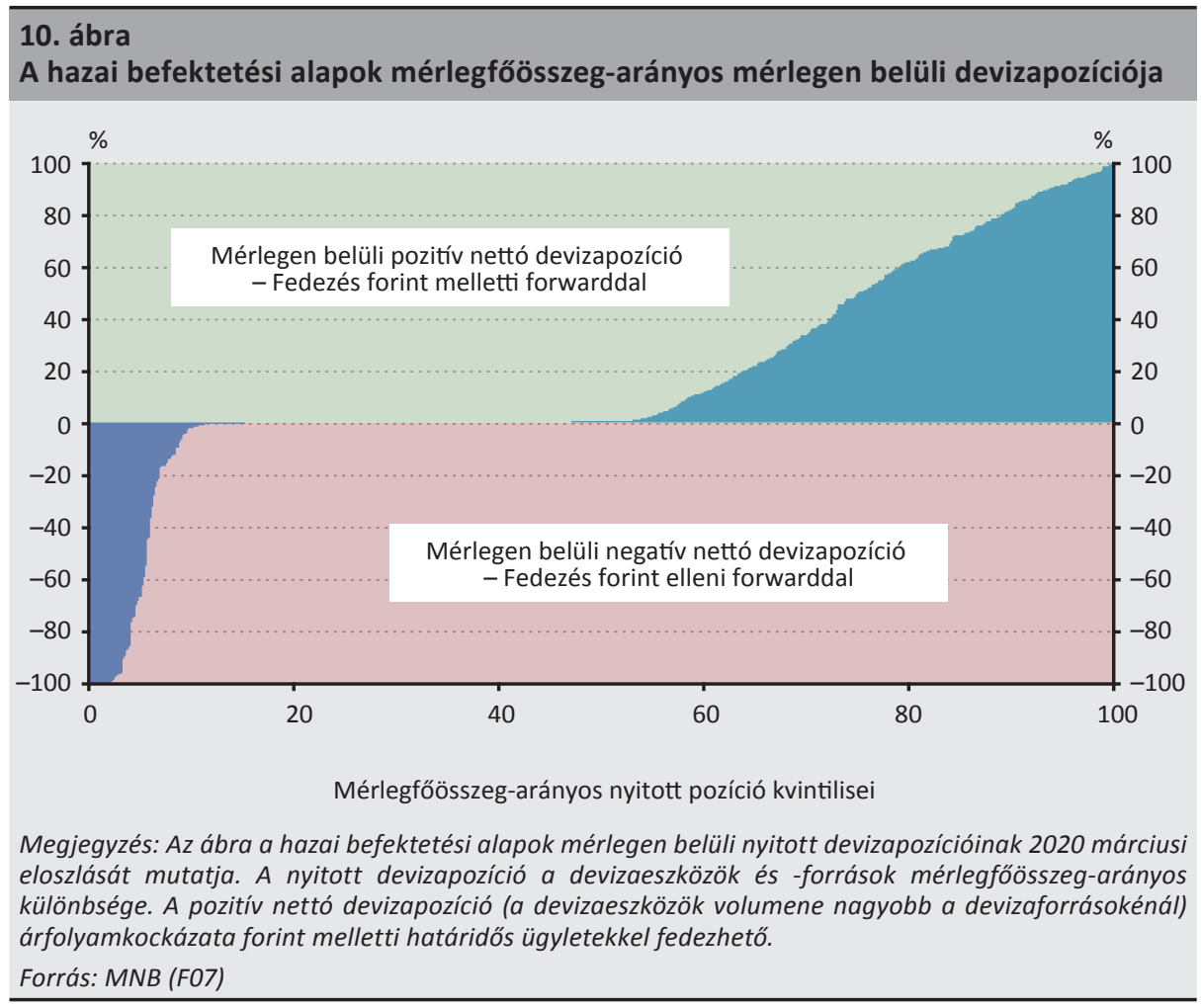

A forint melletti oldalnál jóval kisebb mértékben, de a befektetési alapok aktívak a forint elleni oldalon is. Ezt azoknak az alapoknak a tevékenysége indokolhatja, amelyek devizaforrásból fektetnek be a hazai értékpapír- vagy ingatlanpiacon. A hazai befektetési alapok által kibocsátott befektetési jegyek állományának mintegy ötöde áll fenn devizában, túlnyomó részben euróban. E források egy része forinteszközöket finanszíroz - így a befektetési alapok kb. tizedének devizaforrásai meghaladják a devizaeszközeik állományát. Ezek a befektetési alapok a mérlegen belüli negatív nettó devizapozíciójuk miatt - feltéve, hogy legalább részben fedezni akarják a forinteszközök és devizaforrások okozta árfolyamkitettséget - forinteladóként jelennek meg a határidős piacon.

Szektorszinten a befektetési alapok mérlegen belüli pozitív nyitott devizapozíciója a teljes mérlegfőösszeg mintegy 26 százalékát teszi ki, azonban a befektetési stratégiától függően az egyes alaptípusok között jelentős különbségek mutatkoznak (11. ábra). A legnagyobb mérlegen belüli devizapozíció a részvényalapoknál és a nemzetközi (elsősorban részvény-, származtatott, garantált és vegyes) alapoknál áll fenn, ezek az alaptípusok rendelkeznek jelentős külföldi eszközállománnyal. Emellett az ingatlanalapok mérlegen belüli devizakitettsége is jelentős: a devizában fennálló eszközeik a devizaforrásaik kétszeresét teszik ki. Az ingatlanalapok relatíve jelentős 
mérlegen belüli nettó devizapozícióját egyrészt az indokolja, hogy a hazai irodapiacon és a kereskedelmi ingatlanok esetén általános az euróban történő elszámolás ${ }^{9}$ (az alapok egyik fő bevételi forrását, a bérleti díjakat jellemzően euróban számítják), az alap viszont forintban számol el a befektetőkkel. Emellett az ingatlanalapok eszközportfóliójának földrajzi diverzifikációja szempontjából is felmerülhet a külföldi eszközökbe - közvetlen vagy közvetett módon ingatlanba fektető kollektív befektetési értékpapírokba vagy nem ingatlancélú pénzügyi eszközökbe - történő befektetés. A hazai egyéb (származtatott, vegyes, kockázati tőke) alapok és a pénzpiaci alapok esetén a legalacsonyabb a devizakitettség: e befektetési alapok portfóliójában alacsonyabb a külföldi befektetések súlya, és eszközeik összetételével összhangban áll a finanszírozás devizaösszetétele.

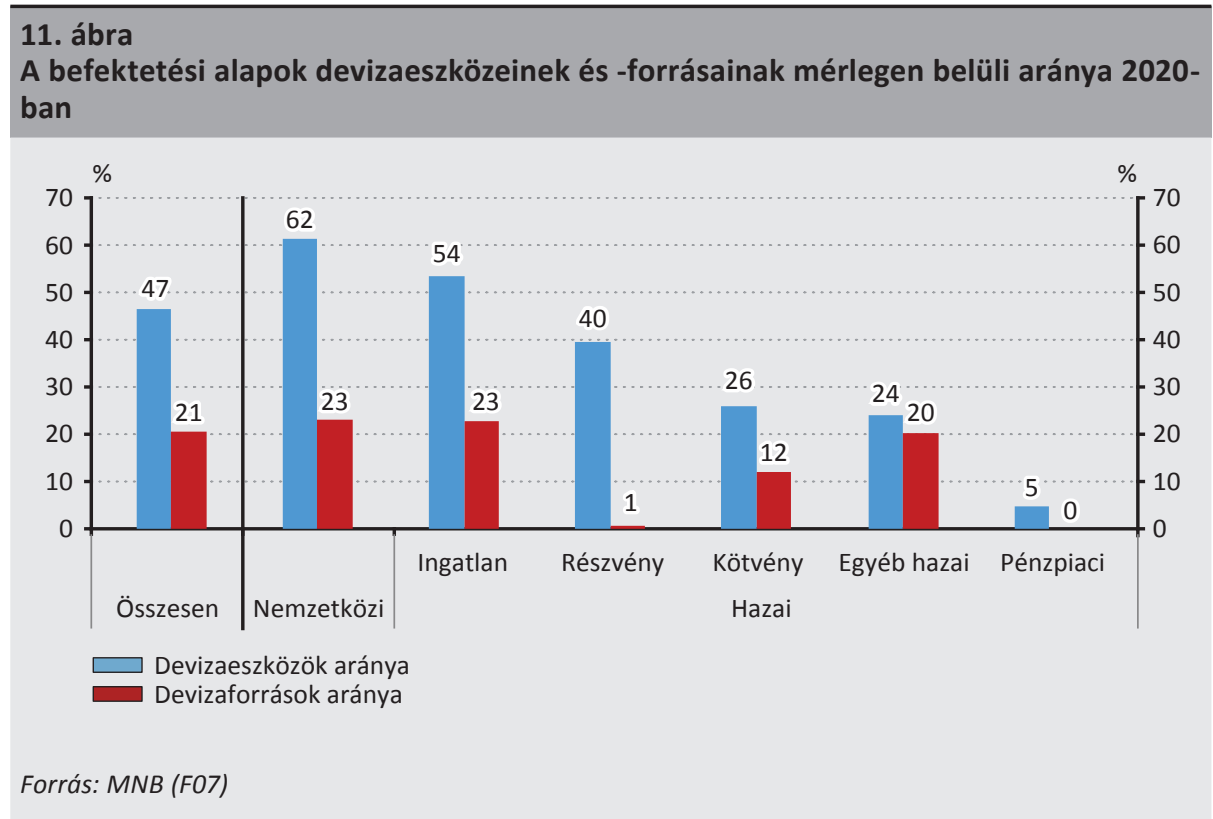

A befektetési alapok devizakitettsége összességében közel 1800 milliárd forinttal nőtt 2009 óta, ami elsősorban a nemzetközi alapokhoz és ingatlanalapokhoz, kisebb mértékben a hazai kötvényalapokhoz kötődött (12. ábra). A befektetési alapok mérlegfőösszeg-arányos nyitott pozíciója azonban kevésbé változott az évek során, 20-30 százalék között alakult, vagyis a devizakitettség nominális összegének növekedése nagyjából az alapok mérlegének bővülésével arányosan történt.

${ }^{9} \mathrm{~A}$ hazai kereskedelmiingatlan-piacról részletesebben lásd az MNB Kereskedelmiingatlan-piaci jelentését (MNB 2020a). 
Először a 2008-as válság utáni kedvező tőkepiaci folyamatokkal összhangban egyre népszerúbb nemzetközi alapokban, majd a 2010-es évek második felétől a hazai ingatlanpiac felfutásával párhuzamosan növekvő ingatlanalapokban tartott vagyon emelkedett, amellyel párhuzamosan az - alacsony hozamkörnyezetben alacsonyabb hozamot biztosító - pénzpiaci alapok és 2017-től a kötvényalapok veszítettek népszerűségükből. A nagyobb devizakitettségű alaptípusok részarányának emelkedése ezáltal a teljes befektetésialap-szektor nettó devizapozíciójának növekedését is magával vonta. Valamelyest érzékelhető az együttmozgás a mérlegfőösszeg-arányos nyitott pozíció és a nemzetközi alapok nettó devizapozíciójának változásával is.

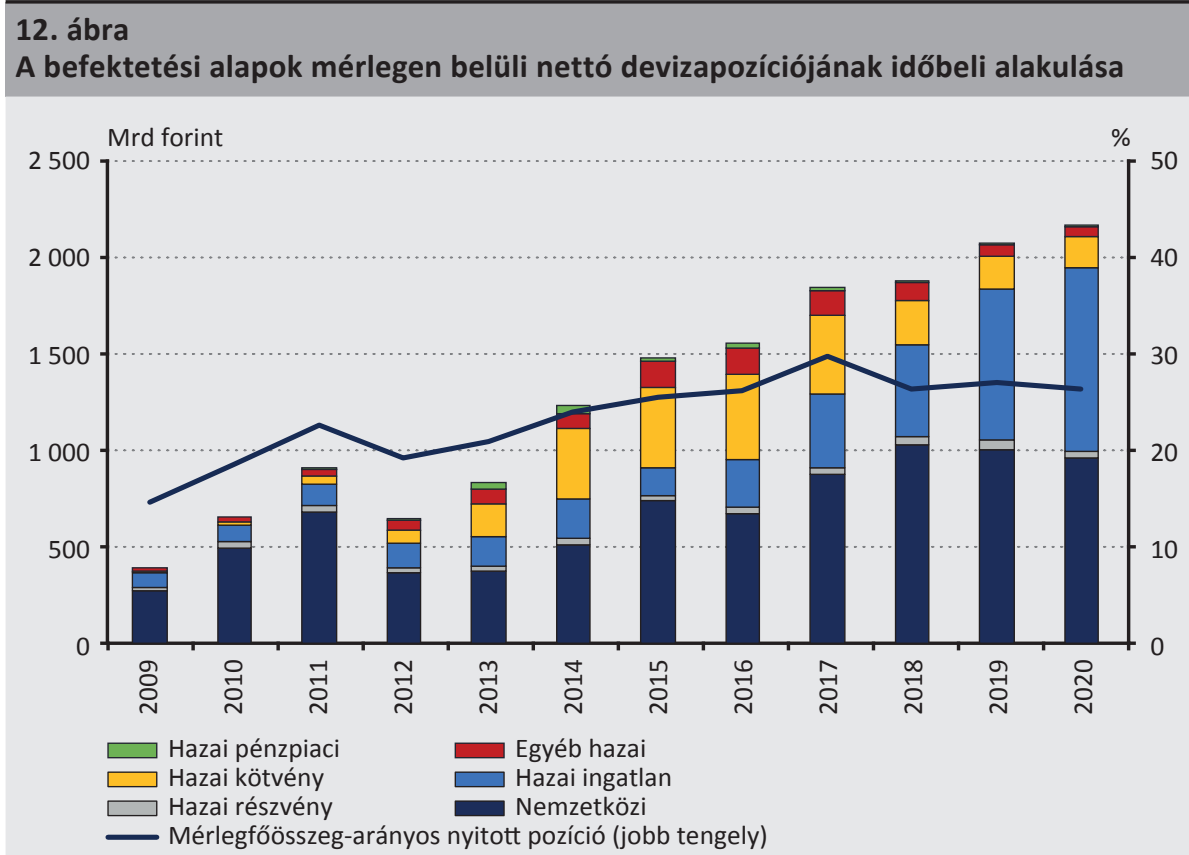

Forrás: MNB (FO7)

A befektetési alapok teljes bruttó forward-állománya és nettó forint melletti állománya a befektetési alapok mérlegének és teljes nettó devizapozíciójának megfelelően a D01-adatok alapján trendszerǔen nőtt az elmúlt évtizedben, ${ }^{10}$ igaz, 2017

\footnotetext{
${ }^{10}$ A D01-adatok alapján a befektetési alapok forward-állományára nincs közvetlen megfigyelés, csak becslés. Az adatforrások ismertetésénél említettük, hogy a 2017 óta rendelkezésre álló M05 jelentés alapján szektorális bontásban, így befektetési alapokra vonatkozóan is látjuk a forward-állományok havi alakulását. A régebb óta rendelkezésre álló D01 jelentésben sok tranzakciónál a bank a konkrét partner azonosítóját is megjelöli, amiből befektetési alaptípusokra is aggregálni lehetne az állományokat. Ugyanakkor a D01-M05 2017-2020 közötti konzisztenciavizsgálata alapján ez a partnerazonosítás nem teljes körü: néhány bank az ügyleteket az anonim kategóriában jelenti, ami miatt a D01-alapú aggregálás az M05-alapú állomány mintegy felét teszi ki. Kétféle becslésünk: (1) az érintett bankok alapokkal kötött forward-állományának becslése a 2017-2020 M05-adatok alapján és (2) az érintett bankok elhagyása a mintából is a trendszerű emelkedés mellett szól.
} 
óta - az M05-adatok alapján - a nettó forint melletti forward-pozíció csökkent. Az M05-adatok alapján 2017-ben a mérlegen belüli nyitott devizapozíció még mintegy felét fedezte a befektetési alapok forward-állománya (13. ábra). A nyitott pozíció fedezése erről a szintről 25-30 százalékra mérséklődött az utóbbi években, tehát a devizakockázat-kitettség nagyobb részét vállalták fel a befektetési alapok.

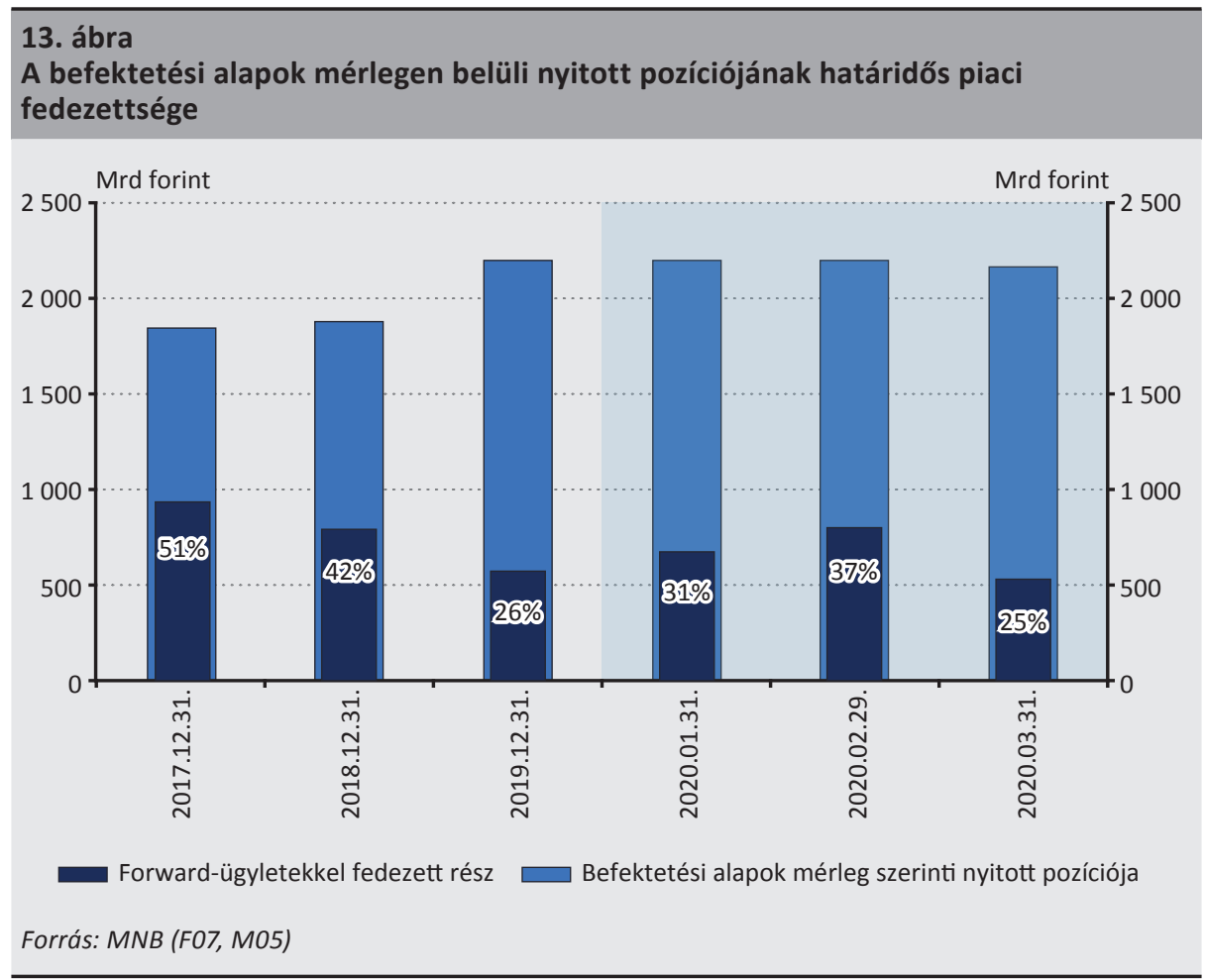

A csökkenő nettó forward-állomány ebben az időszakban tehát kevéssé összeegyeztethető kockázatkezelési szempontból az aggregált devizakitettséggel, ami az állomány emelkedése mellett szólt volna. A nagyobb árfolyampozíció vállalása mellett szólhatott a forintkamatok relatív csökkenése például az emelkedő dollárhozamok viszonylatában, ami a határidős ügyletek carry-költségének növekedésével járt. Elképzelhető, hogy az éretté váló konjunktúraciklusban az alapok egyre inkább a feltörekvő devizák és így a forint leértékelődésére számítottak, vagy a piaci feszültségek emelkedése mellett az árfolyam és a nemzetközi részvények erősebb negatív korrelációjára, ami szintén kisebb árfolyamfedezettség mellett szólt volna. 


\section{Határidős állományok árfolyam-érzékenysége}

Ebben a fejezetben a forward-kötések időben változó árfolyam-érzékenységének becslésével foglalkozunk.

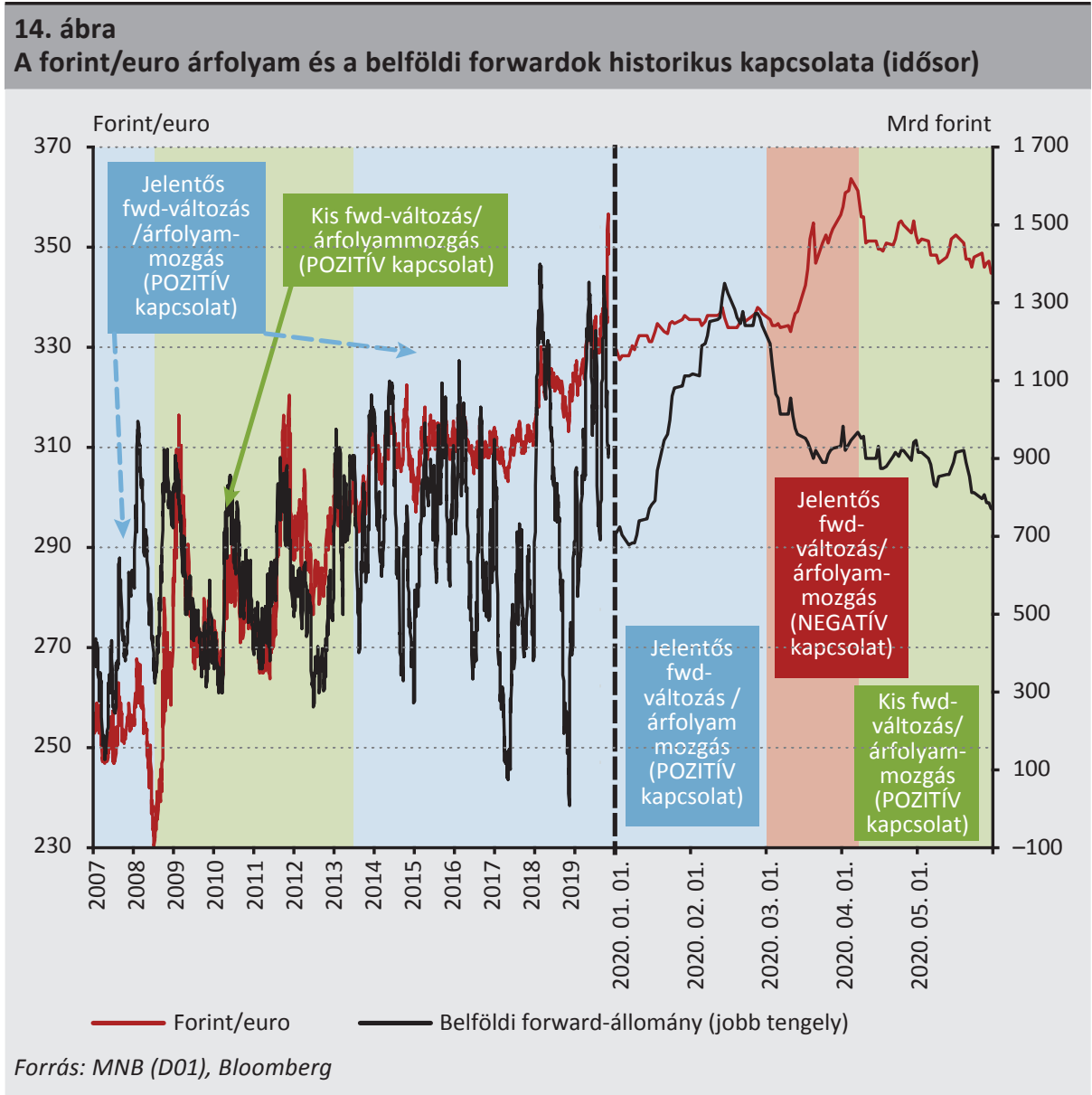

Banki interjúink, a korábbi szakirodalom (Csávás et al. 2006) és az adataink is megerősítik, hogy a belföldi forward-állomány érdemben reagál a forintárfolyam mozgására. Amikor a forint gyengül, a belföldiek növelik a határidős forintvételi állományaikat, ami a forint stabilitására vonatkozó várakozásokat és aszerinti spekulációt tükrözhet. Ha az árfolyamra visszahatnak a forward-kötések, akkor ez negatív irányú visszacsatolást jelent, tehát a forintot stabilizáló tényező. 
Ugyanakkor a forward-állomány árfolyam-érzékenysége időszakosan érzékelhetően változott, sőt 2020 márciusában időlegesen negatív irányú kapcsolatot is láttunk, amikor a forint-euro árfolyam emelkedett, és a belföldiek nettó forint melletti forward-állománya csökkent (14. ábra).

Az időben változó érzékenység megragadására a forwardok és árfolyam között egy időben változó paraméter modellt becslünk. A modellben a forint-euro árfolyamot exogénnek feltételezzük. ${ }^{11}$

A modell megfigyelési egyenlete:

$$
\Delta F W D_{t}=c_{0 t}+c_{1 t} \Delta F W D_{t-1}+\beta_{0 t} \Delta \mathrm{EURHUF}_{t}+\beta_{1 t} \Delta \mathrm{EURHUF}_{t-1}+\varepsilon_{\mathrm{t}}, \varepsilon_{t} \sim N(0, R) \text {. }
$$

ahol $\triangle F W D_{t}$ a forward-állomány logaritmusának változása, ${ }^{12}$ amit egy árfolyamtól független tényező $\left(c_{0 t}\right)$, egy autoregresszív tényező ( $c_{1 t}$ paraméterrel), a logaritmikus árfolyam változásának és késleltetettjének ( $\left[\beta_{0 t}, \beta_{1 t}\right]$ paraméterekkel) hatásaira, illetve egy normáleloszlású hibatagra $\left(\varepsilon_{\mathrm{t}}\right)$ bontunk.

Jelölje $B_{t}$ a $\left[c_{0 t}, c_{1 t}, \beta_{0 t}, \beta_{1 t}\right]$ látens paraméterek vektorát egy adott időpontban. Ezeknek a paramétereknek az időbeli dinamikájára random walk feltételezéssel élünk:

$$
B_{t}=B_{t-1}+v_{t}, v_{t} \sim N(0, Q)
$$

a paraméterek innovációja $\left(v_{t}\right)$ normáleloszlású diagonális kovarianciával $(Q)$.

A modell becslését EM (Expectation-Maximization) algoritmussal (Dempster et al. 1977) végezzük a 2003-2020 között rendelkezésre álló D01 (napi frekvenciájú)-adatok alapján. A becslés technikai részleteiről és robusztusságvizsgálatáról a Függelékben írunk.

\footnotetext{
${ }^{11}$ Itt nem közölt VAR-modellek segítségével általánosabb modelleket is vizsgáltunk, amelyek az árfolyam, a külföldiek spot-tranzakciói és a forwardok (különböző szektorális megbontásokban) kölcsönhatásait is megengedik. Granger-kauzalitás-tesztek alapján a forward (és a külföldiek belföldi bankokkal kötött spot-) tranzakciók késleltetetten nem hatnak szignifikánsan az árfolyamra. A szimultán (napon belüli) hatás ettől még lehet jelentős, de ennek mértékét (napi tranzakciós adataink alapján) nem tudjuk identifikálni. A globális forintpiachoz mérten kisebb hazai kereskedés mérsékelt hatást valószínúsít. Minél jelentősebb a forward-állomány visszahatása az árfolyamra, annál jobban alulbecsüljük a modellben az azonnali árfolyam-érzékenység paraméterét.

${ }^{12}$ A Függelékben robusztusságvizsgálatként bemutatjuk a becsléseket a modell olyan változataira, amelyekben az állomány változása helyett a tranzakciók (új forward-kötések volumene) a függő változó. Ezekkel a modellekkel is hasonló eredményekre jutunk.
} 


\section{5. ábra \\ A belföldi forward-állományok árfolyam-érzékenysége}

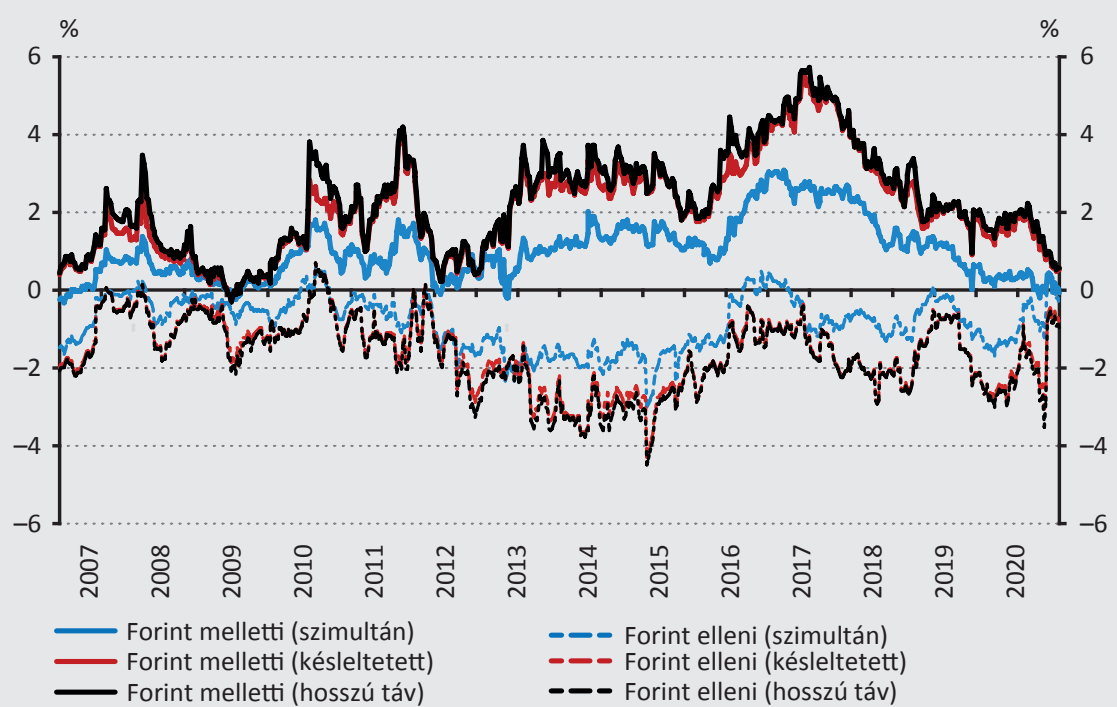

Megjegyzés: Szűrt modellparaméterek alapján számított árfolyam-érzékenység idősorok (1 százalékos árfolyamváltozás - forintgyengülés - százalékos hatása az állományváltozásra). Kék vonalak a szimultánhatást $\left(\beta_{0}\right)$, a pirosak a szimultán- és késleltetett hatás összegét $\left(\beta_{0}+\beta_{1}\right)$, a fekete vonalak a feltétel nélküli (hosszú távú) hatást mutatják $\left(\left(\beta_{0}+\beta_{1}\right) /\left(1-\left|c_{1}\right|\right)\right)$. A folytonos vonalak a forint melletti (a bank ügyfele szempontjából határidős forintvétellel járó) állományok, a szaggatott vonalak a forint elleni (a bank ügyfele szempontjából határidős forinteladással járó) állományok érzékenységére vonatkoznak.

Forrás: Az MNB (D01) és Bloomberg adatok alapján számítva

A 15. ábra bemutatja a belföldi forward-állomány (szimultán, két periódusú és hosszú távú) árfolyam-érzékenységének alakulását a becsült (szűrt) paraméterek alapján. A forint melletti ügyletek esetében a paraméterek pozitívak, ami megerősíti, hogy a belföldi ügyfelek körében nőtt a forint melletti határidős állomány a forint gyengülésekor (a forint-euro árfolyam emelkedésekor). Ezzel szemben a határidős forinteladási ügyletek volumene a forint erősödésekor emelkedett (a forint elleni paraméterek negativitása alapján).

Korábbi válságidőszakok egy lényeges közös jellemzőjét megerősíti a becslésünk. Mind a 2008 végi periódusban, mind 2011-2012 környékén és idén a koronavírus járvány során látványosan csökkent a forwardok érzékenysége az árfolyamra, tehát ezekben az időszakokban jóval nagyobb árfolyammozgások váltottak ki olyan méretű forward-kötéseket, amelyeket normál időszakokban már kisebb árfolyammozgásoknál láttunk. Bár kötési volumenekben nincs szisztematikus csökkenés ezekben az időszakokban, az egységnyi árfolyam-elmozdulásra jutó kötési volumen csökken. 
A lecsökkent árfolyam-érzékenység ezekben az időszakokban többféleképpen interpretálható. Egyik lehetőség, hogy a bankok ügyfélköre óvatosabbá válik (például a megemelkedett/várhatóan emelkedő volatilitás és a potenciálisan veszteségessé váló derivatív ügyletek nagyobb likviditásigénye miatt), és bár megmarad az árfolyam átlaghoz visszahúzására vonatkozó várakozása, az ügyfelek valamelyest kivárnak, és csak nagyobb árfolyammozgás mellett lépnek piacra. Elképzelhető, hogy a már megemelkedett volatilitás és szükös likviditás periódusaiban az ügyfelek, bár szeretnének, de nincs likviditási/tőke kapacitásuk felvállalni az árfolyam visszaerősödésére játszó pozíciókat. További interpretáció, hogy az ügyfelek várakozásai megváltoznak vagy legalább az ügyfélkör heterogénebbé válik, és egy részük elbizonytalanodik az árfolyam átlaghoz történő visszahúzását illetően.

Elvileg az is lehetséges lenne, hogy ezekben az időszakokban gyengül a belföldi szereplők hatása az árfolyamra. A modell szimultaneitási problémája miatt, ha a forward-kötések visszahatnak az árfolyamra, akkor az (abszolút értékben) növeli a becsült paramétereket a valós árfolyamhatáshoz képest. ${ }^{13}$ Tehát elvileg a lecsökkent paraméter lehet a kisebb árfolyamra gyakorolt visszahatás eredménye is. Ugyanakkor a piacon ilyenkor látott (és anekdotikus információkból hallott) alacsony likviditás nem teszi valószínúvé ezt a magyarázatot: illikvid piacokon azonos kötési mennyiségeknek inkább nagyobb lehet az árhatása.

\footnotetext{
${ }^{13}$ Például a forint melletti ügyletek esetében egy egységnyi árfolyamsokk megemeli a forwardokat, de ez visszacsökkenti az árfolyamot, tehát nagyobbnak látjuk a megfigyelt árfolyammozgásra vetített forwardváltozást, mint amit az eredeti sokk eredményezett.
} 


\section{6. ábra}

Árfolyam-érzékenység szektorális bontásban (2017-2020, illetve 2020. január május)

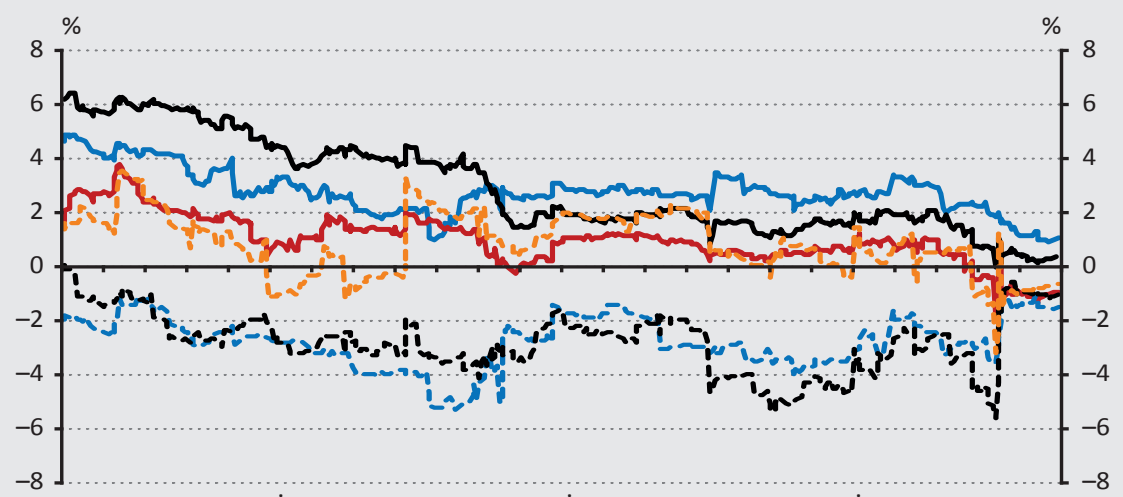

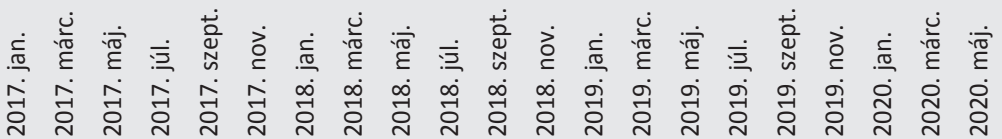

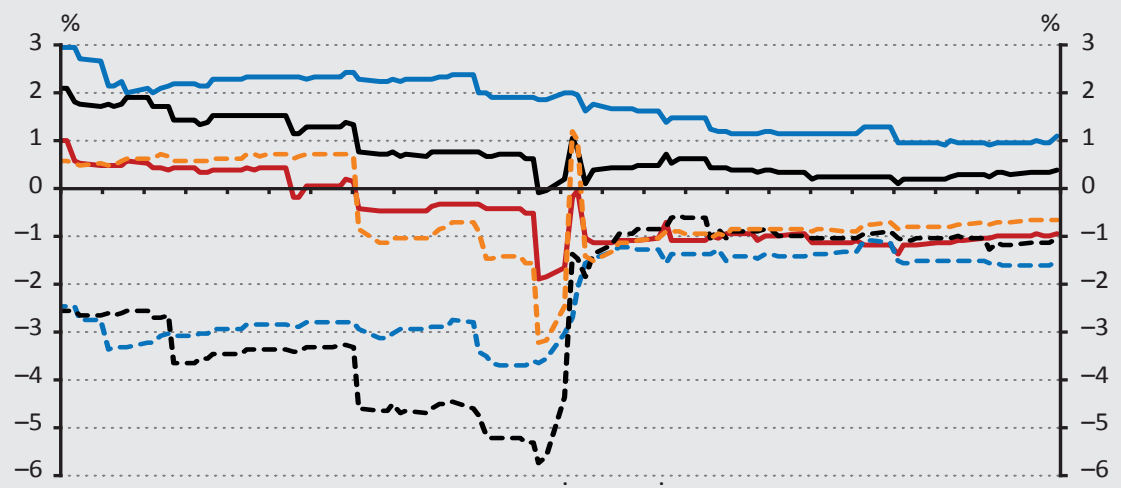

\begin{tabular}{|c|c|c|c|c|c|c|c|c|c|c|}
\hline નં & نे & ஓ่ & 국 & $\stackrel{\bullet}{N}$ & 号 & $\stackrel{\text { ก }}{\sim}$ & $\infty^{\infty}$ & $\underset{N}{N}$ & ஜீ & ণ \\
\hline 完 & $\frac{\dot{c}}{\text { d }}$ & $\frac{\grave{0}}{4}$ & $\frac{\frac{1}{0}}{4}$ & $\frac{\dot{0}}{4}$ & है & है & 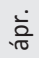 & $\frac{\grave{2}}{-1}$ & 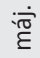 & 浣 \\
\hline $\begin{array}{l}\text { ㅇ } \\
\text { O }\end{array}$ & $\begin{array}{l}\text { ঠ் } \\
\text { O্ }\end{array}$ & 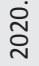 & 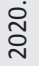 & 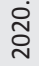 & 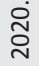 & 옹 & 요 & 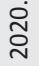 & 용 & 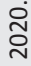 \\
\hline
\end{tabular}

\footnotetext{
Nem pénzügyi (forint mellett)

Pénzügyi (forint mellett)

- Nem pénzügyi (forint ellen)

Pénzügyi (forint mellett)

- Pénzügyi (forint ellen)

- Befektetési alapok (forint ellen)
}

Megjegyzés: forward-állományok árfolyam-érzékenységének alakulása (1 százalékos árfolyamváltozás - forintgyengülés - százalékos szimultán+késleltetett hatása az állományváltozásra) a D01-adatokból elérhető szektorális bontás szerint, szürt modellparaméterek alapján. Kék vonalak a belföldi nem pénzügyi szektorra (vállalatok/lakossági ügyfelek), a fekete a belföldi pénzügyi szektorra, a piros/narancssárga a befektetési alapokra vonatkoznak. Folytonos vonalak jelölik a forint melletti, szaggatott vonalak a forint elleni állomány árfolyam-érzékenységét.

Forrás: Az MNB (D01) és Bloomberg adatok alapján számítva 
A D01-adatok alapján becslésünk van a bankok belföldi ügyfélkörének szektorális bontására, és ez alapján az egyes szektorok eltérő árfolyam-érzékenységét is becsülni tudjuk (16. ábra). ${ }^{14} 2017$ és 2020 között a pénzügyi és a nem pénzügyi ügyfélkörre is jellemző volt a forint melletti állomány árfolyam-érzékenységének tendenciózus csökkenése. Ezt részben magyarázhatják a banki megkérdezések során említett tényezők, az tehát, hogy a hazai és külföldi kamatok közti különbözet csökkenése, illetve a forint gyengülése ebben az időszakban mérsékelte a forint átlaghoz való visszahúzására vonatkozó spekulációt.

Feltűnő, hogy a befektetési alapok forward-állományának árfolyam-érzékenysége markánsan különbözik a teljes pénzügyi ügyfélkör hasonló mutatójától. Az alapok esetében sokkal alacsonyabb (bár szintén pozitív) a forint melletti állomány árfolyamra vett érzékenysége, de igazán látványos különbség a forint elleni (devizavételi) állományok esetében látható, amely - ellentétben a többi ügyfélkörrel - a forint gyengülésekor és nem a forint erősödésekor emelkedik. Ez arra utal, hogy a befektetési alapok körében a nem pénzügyi ügyfelekhez (és más pénzügyi szereplőkhöz képest) jóval kisebb a forint stabilitására vonatkozó spekuláció. Ugyanakkor a nettó állomány még mindig a forintárfolyammal pozitívan korrelál, mert a forint melletti állományok volumene lényegesen nagyobb a forint elleni állományoknál, így a százalékosan hasonló mértékű elmozdulások a forint melletti állomány a forint elleniekhez képest nagyobb emelkedésével jár.

A 16. ábra alsó panelje alapján 2020-ban a forint melletti forwardok árfolyam-érzékenysége fokozatosan csökkent, azonban az igazán markáns elmozdulásokat a forint elleni oldalon tapasztaltuk. A forint melletti árfolyam-érzékenység a befektetési alapoknál már februárban negatívba fordult, a többi szereplőnél inkább csak a pozitiv együttható értéke mérséklődött. A forint elleni állományok árfolyam-érzékenysége március közepén (a 13-18 közötti forintleértékelődéssel párhuzamosan) ugrásszerűen megemelkedett valamennyi szereplőnél, de csak a befektetési alapoknál váltott előjelet. Ebben a kritikus időszakban az árfolyam megemelkedése mellett az alapok forint elleni állománya nőtt, miközben más pénzügyi és nem pénzügyi szereplőké enyhén, de mérséklődött.

\footnotetext{
${ }^{14} \mathrm{Az}$ adatszolgáltatók többsége a pénzügyi ügyfelekkel kötött tranzakciókat partnerazonosítóval jelenti a D01 jelentésben, amiből a pénzügyi szektor szereplőinek forward-állományát, azon belül a befektetési alapok állományát tudjuk becsülni. 2017 és 2020 között rendelkezésre álló M05 jelentés alapján tudjuk pontosítani a becslést (kiszűrni a mintából azokat az adatszolgáltatókat, ahol a D01-M05 szektorális állományok különböznek).
} 


\section{A 2020. márciusi turbulencia a devizapiacon}

2020 márciusában a három legjelentősebb belföldi határidős devizapiaci ügyfélkör (nem pénzügyi vállalatok, befektetési alapok és egyéb pénzügyi vállalatok) nettó forint melletti állománya csökkent az árfolyam jelentős emelkedése mellett, így a hagyományos kapcsolat megfordult (8. ábra).

\subsection{A forint melletti pozíció záródása elsősorban a befektetési alapok pozíciójából következett}

A befektetési alapok (és ezzel párhuzamosan a teljes belföldi pénzügyi szektor) idén január-februárban a forint kismértékú gyengülése mellett növelték a nettó forint melletti kitettségüket, majd márciusban a befektetési alapok körében regisztrálhattuk a legnagyobb mértékú visszaesést a forint melletti pozíciókban. A méretükből következően kisebb mértékben, de az egyéb hazai pénzügyi szereplők (biztosítók, pénztárak, egyéb közvetítők) forint melletti kitettségének leépítése is csökkentőleg hatott a teljes belföldi határidős pozicionáltságra. A nem pénzügyi vállalatok viszont nem változtatták számottevően határidős pozíciójukat.

Finanszírozási oldalról a forint melletti nettó pozíció leépítését indokolta, hogy a COVID-19 hatására kialakult márciusi piaci turbulencia következtében jelentős tőkekivonás történt a befektetési jegyekből, tehát az alapok forrásai - és így a befektetett eszközeik is - csökkentek (17. ábra). A befektetési alapokat finanszírozó befektetési jegyek állományában a legnagyobb visszaesés a nemzetközi alapok esetében, ezen belül is elsősorban a nagyobb tőkepiaci kitettséggel rendelkező származtatott (spekulációs pozíciókat vállaló), a részvény- és a vegyes (kötvény és részvénykitettséggel egyaránt rendelkező) - alapoknál történt. Az ingatlanalapok finanszírozásában - ahol a befektetések értékére a veszélyhelyzet nem volt közvetlen és azonnali hatással - nem történt számottevő visszaesés, a befektetési jegyekben tartott vagyon relatíve stabil maradt. A többi hazai alaptípusnál csökkent ugyan a befektetési jegyek állománya, azonban a szektor alacsony devizakitettsége miatt ennek kisebb hatása lehetett a határidős devizapiacra. 


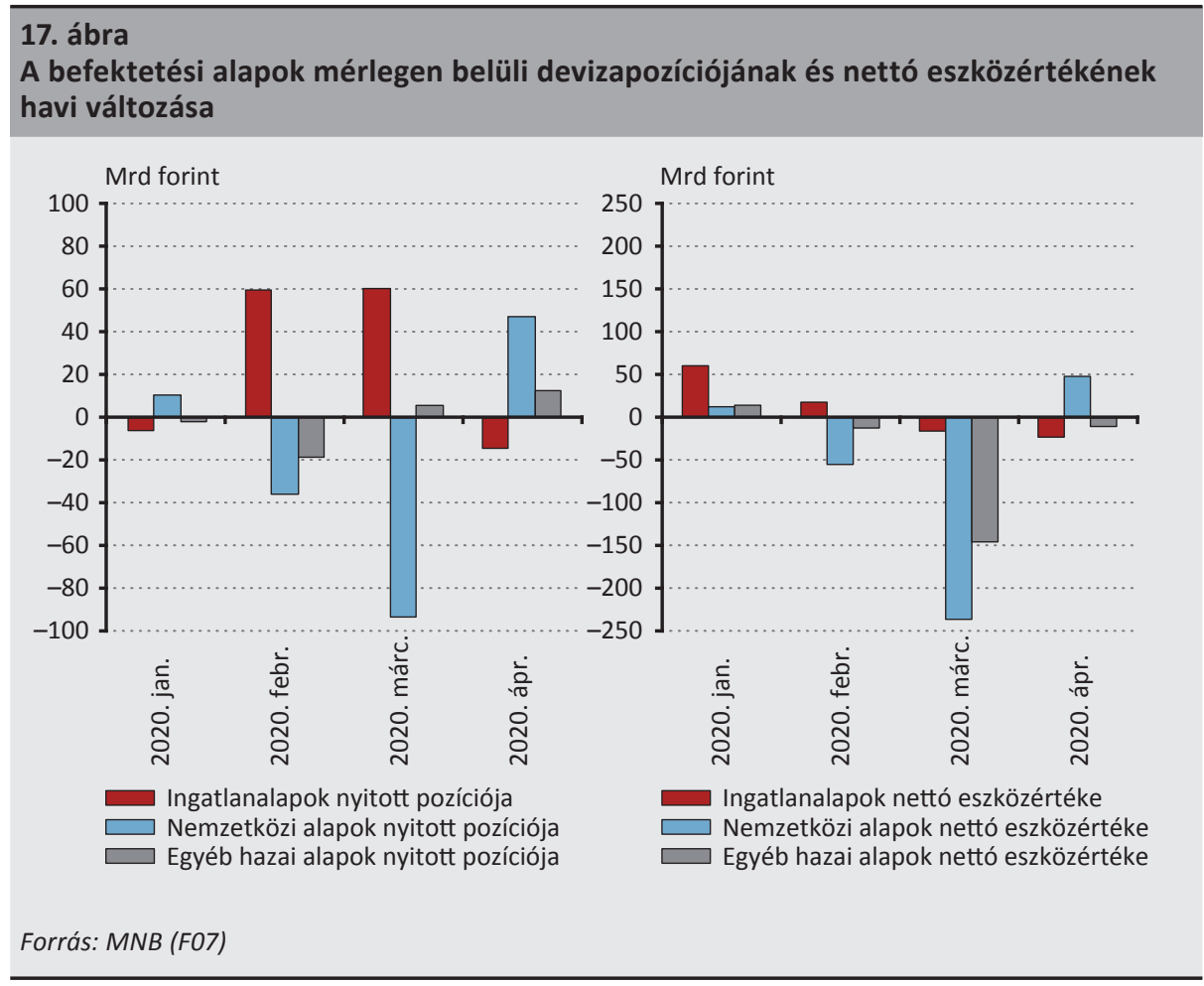

Eszközoldalon a befektetési alapok árfolyamkockázatának fedezési igényét csökkentette (az említett forráskivonás miatt likvidált eszközportfólión túl), hogy a mérlegen tartott devizaeszközök piaci értéke is jelentősen csökkent, elsősorban a tözsdei részvényárfolyamok globálisan jellemző esése következtében. Mindez szintén elsősorban a nemzetközi alapokat érintette, azon belül is a - jellemzően magasabb kockázati osztályba tartozó - származtatott, illetve részvényalapokra volt nagyobb befolyással. A devizaeszközök forintértékének változását másik oldalról ugyanakkor ellensúlyozta a forint föbb devizákkal szembeni márciusi jelentős leértékelődése. Ez a devizakövetelések (és az ennél kisebb devizakötelezettségek) forintban kifejezett értékének emelkedését okozta.

Aggregált szinten ez a két hatás - a nemzetközi eszközök értékcsökkenése és a forint leértékelődése - nagyjából kioltotta egymást az alapok devizaeszköz-állományának tekintetében (18. ábra). Ez különösnek tűnhet, tekintve a részvénypiaci árfolyamok lényegesen nagyobb (40 százalék körüli) csökkenését a forint (10 százalék alatti) gyengüléséhez képest. Mindezt az magyarázhatja, hogy a befektetési alapoknak csupán egy része ( $p l$ részvényalap, származtatott alap) vállal magasabb kockázatot, és a jelentősebb részvénypiaci kitettséggel rendelkező befektetési alapok is csak az eszközeik bizonyos részét fektetik kockázatos eszközökbe. Ezzel szemben az alapok többsége jelentős devizaeszköz-állománnyal rendelkezik. Így, bár a részvényárfolya- 
mok zuhanásához képest a forint árfolyamának leértékelődése jóval kisebb mértékü volt, de utóbbi hatás a befektetési alapok szélesebb körét és nagyobb eszközállományt érinthetett, mint az eszközök árváltozása.

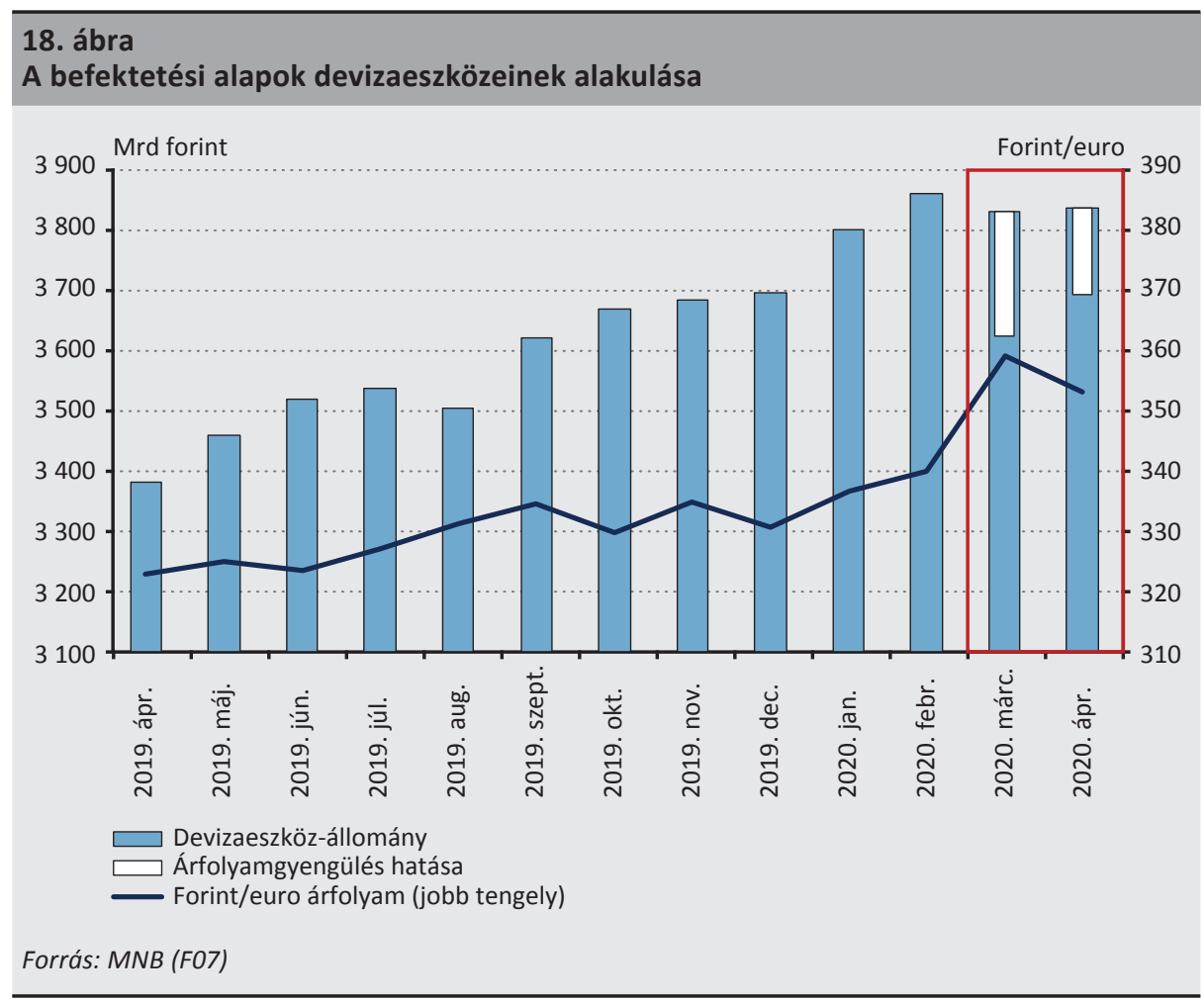

A befektetési alapok határidős devizapiaci ügyletkötését ezek mellett az is befolyásolhatta, hogy a korábban megkötött forint melletti határidös ügyletek az árfolyam emelkedésével párhuzamosan veszteségessé váltak. A pénzügyi szereplők esetében a jelenlegi európai szabályozások kötelező napi margin-értékelést írnak elő, és a veszteséges határidős ügyletekre a bankok pótfedezetet kérnek be (margin call). Tovább rontotta a helyzetet, hogy a piaci volatilitás emelkedése miatt a fedezeti limiteket is szúkítették, ami a pozíciók továbbgörgetéséhez további fedezet biztosítását tette szükségessé. A likviditáshiányos szereplök számára a pótfedezeti igény szintén a határidős (forint melletti) pozíciók zárása mellett szólt: a pozíciók lezárásával (forint elleni ügylet megkötésével) csökkenthető volt az ebből keletkező likviditási igény. 


\subsection{Az exportőrök távol maradtak a határidős piactól az árfolyam számottevő gyengülése ellenére}

A nem pénzügyi vállalatok esetében a határidős pozíció csökkenése már 2020. februárban megkezdődött, és alapvetően márciusban nem volt jelentős mértékü, inkább a historikus pozitív irányú együttmozgáshoz mérten (az ebből következően várható megugráshoz képest) tűnik váratlannak a kisebb csökkenés. Ezek alapján az exportőrök februárban és márciusban nem biztosítottak támaszt a forint árfolyamának.

A banki beszámolók az exportőrök esetében a befektetési alapoktól eltérő jellegű motivációkat emeltek ki. Az egyik, szinte konszenzusosan említett oka a forint leértékelődéséhez képest kisebb forint melletti pozíciófelvételnek az volt, hogy azok a szereplők, akik az exportbevételeik árfolyamkockázatát fedezni kívánták, már korábban, 330-340-es árfolyam mellett beléptek a piacra, így a forint további gyengülésekor a túlfedezettség elkerülése érdekében már nem tudtak további forint melletti pozíciókat vállalni.

Néhány banki interjúban az ezenfelül említett további okok inkább a már korábban említett hosszabb távú trendekhez és kevésbé a márciusi fejleményekhez kötődtek. Ezek alapján az exportőrök általában kisebb részvételét a hazai deviza elmúlt években látott gyengüléséhez és az alacsonyabb kamatkülönbözethez kapcsolták, amelyek a hagyományos, forintstabilitásra irányuló, spekulatív motivációjú kereskedést általában csökkenthették.

Elvileg határidős ügyletekből való „kistoppolódások” is okozhatták volna a vállalati nettó forint melletti pozíciók stagnálását, de ezeket banki interjúink szintén nem erősítették meg. Mint említettük, a bankok többségénél a vállalati szektor esetében ritkák a kényszerú pozíciózárások, és márciusban sem voltak jellemzőek.

Szintén kevesen gondolták relevánsnak a márciusi folyamatokban az exportbevételek várt visszaeséséhez kapcsolódó pozíciózárásokat. Ezzel kapcsolatban ismét a vállalatok prudens fedezettségét említették többen, bár voltak, akik a következő hónapokra várták a bevételek visszaeséséből eredő határidős kitettségek csökkentését.

\subsection{A nettó határidős pozíció változása elsősorban a forint elleni állomány felfutásához köthető}

A bruttó forint melletti állomány stagnált a februári felfutás óta, ez tehát alátámasztja az exportőrök távolmaradásáról szóló információkat. Ugyanakkor fontos hangsúlyozni, hogy továbbra is történtek forint melletti pozíciónyitások, de ezek inkább csak a korábbi magas forint melletti állományok lejáratainak ellensúlyozását tették lehetővé. 


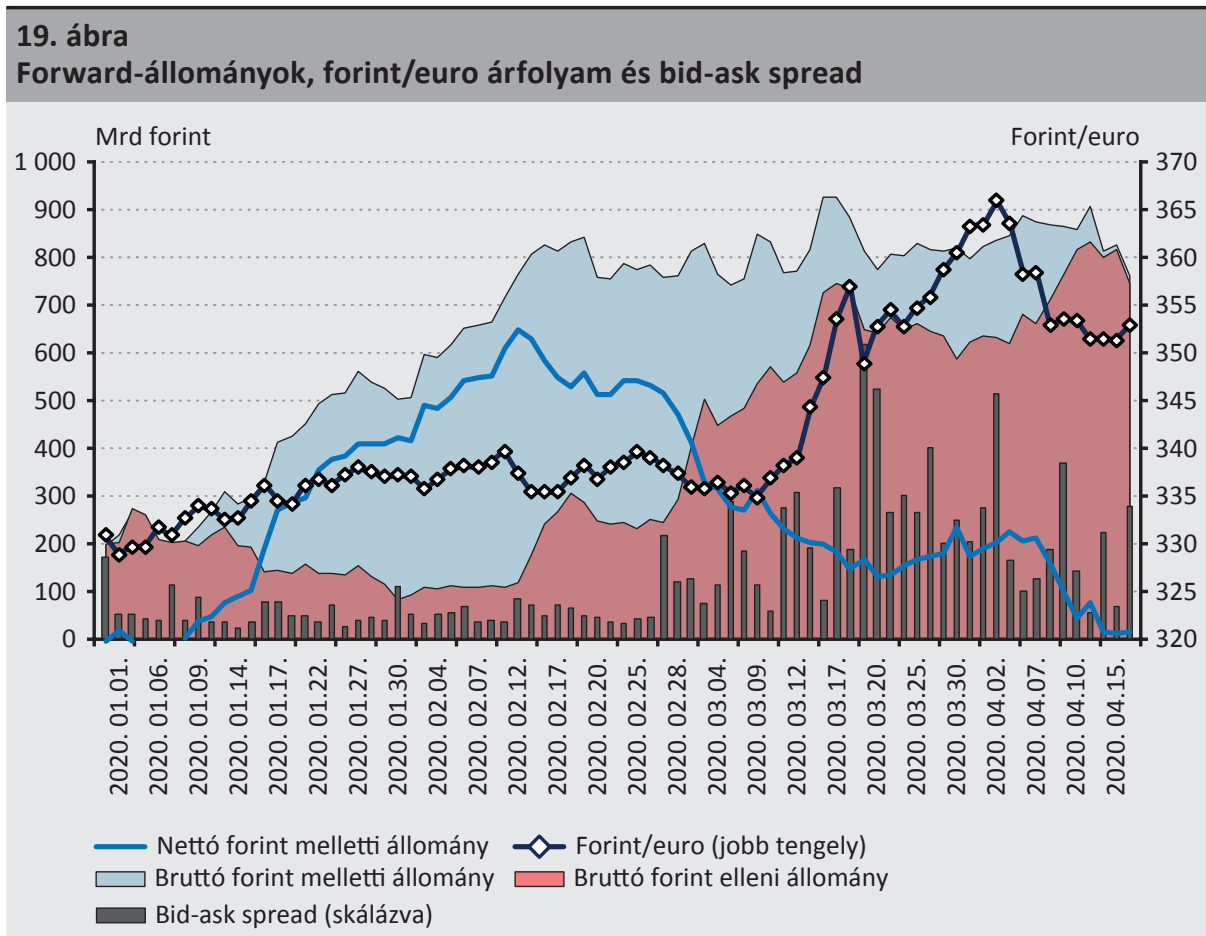

Megjegyzés: Belföldi határidős forint melletti és forint elleni pozíciók év elejétől kumulálva (skálázás érdekében 2020.01.01=200 mrd forint). Forint/euro bid-ask spreadek skálája az ábrához igazítva (a valós skálájuk 0,1 és 7 forint között mozog).

Forrás: MNB (D01), Bloomberg

A forint elleni oldalon azonban a kötési volumen már február közepétől meghaladta a lejáratokat, itt tehát aktív pozíciónyitásokat láthattunk. Ez részben lehetett óvatossági motívum is a COVID-19-járvány várt gazdasági hatásával kapcsolatban, ezekkel az ügyletekkel piaci szereplők (befektetési alapok) már előre csökkenthették forint melletti kitettségüket, ha a forint gyengülésére számítottak. Az előző fejezetben bemutatott modell alapján ugyanakkor ez kevésbé kapcsolódott közvetlenül a forintárfolyam napi mozgásához, és ezt alátámasztja az is, hogy a forint elleni állományok részben a forint intenzívebb gyengülése előtt kezdtek kiépülni. Február végén az amerikai tőzsdén már látszott a bizalom megingása a VIX-index nagyobb emelkedésében, és a forint azonnali devizapiacon is látható volt a likviditás csökkenése (19. ábra), így a március elején látott forint elleni pozíciókat a nemzetközi alapoknál elszenvedett devizaeszköz-portfólió értékcsökkenése motiválhatta. A későbbi, március közepi újabb forint elleni kötésekben nyilvánulhattak meg a befektetési jegy visszaváltásából és a margin callok likviditás igényéhez kötődő, kényszerű forint elleni tranzakciók. 
Április elején a piaci mozgások mérséklődtek, és megindult a devizapiac, azon belül a határidős devizapiac likviditásának, volatilitásának normalizálódása. A belföldiek nettó forint melletti forward pozíciója tovább csökkent, igaz ekkor a forint erősödése volt jellemző, így itt a hagyományos, azonos irányú együttmozgás érvényesült. Modellbecsléseink alapján azonban a forint stabilitására vonatkozó spekulatív ügyletkötések továbbra is mérsékeltek, az egységnyi forintváltozás által indokolt kötési volumen március közepén a korábbi értékek töredékére esett vissza, és azóta alacsony szinten maradt.

\section{6. Összegzés}

Tanulmányunk áttekinti a hazai határidős devizapiac legfontosabb jellemzőit, különös tekintettel a piac szerkezetére és a részt vevő szereplők motivációira. A forintpiac kis részét teszi ki a globális devizapiacnak, de annak trendjei, ügyletenkénti megoszlása hasonló és a forintpiac hazai szegmensére is jellemző. A forint-devizapiac mintegy 10-20 százalékát teszik ki a határidős ügyletkötések.

A hazai piacot korábban átfogóan elemző Csávás et al. (2006) tanulmány sok konklúziója továbbra is érvényes. A hazai határidős piacon - ellentétben a spot- és deviza-swap-piacokkal - a külföldi szereplők alig vállalnak szerepet. A hazai bankrendszer - szabályozási követelmények miatt is - közvetítő szerepet lát el, nyitott devizapozíciót nem vállal. A határidős devizapiacon aktív nem pénzügyi (külkereskedelemben aktiv) vállalatok jellemzően forint melletti pozíciót vállalnak, ami (aggregált szinten) megfelel a hazai nettó exportőr pozícióból következő természetes kitettségnek. A vállalatok ügyletkötéseire továbbra is markánsan jellemző a forint stabilitására vonatkozó várakozásból adódó motiváció. Banki megkérdezések alapján a kamatkülönbözetre építő carry trade jellegú motiváció jelen van még a piacon, de jelentősége mérséklődött az elmúlt években a kamatkülönbözet csökkenése révén.

Elemzésünk ugyanakkor rámutat, hogy a piacon jelenleg a legfontosabb szereplök már nem a külkereskedelemben aktív vállalatok, hanem (hasonlóan a globális színtérhez, pl. Borio et al. 2017; Patel - Xia 2019; Schrimpf -Sushko 2019) a pénzügyi szektor szereplői. Hazánkban az elmúlt öt-tíz év során a pénzügyi szektoron belül is a leginkább meghatározó ügyfélkörré a befektetési alapok léptek elő. A befektetési alapok kitettségei sokban hasonlítanak a nem pénzügyi vállalatokéra: szintén nettó forint melletti pozíciót tartanak fent, amivel a forintfinanszírozású devizaeszközökből adódó devizakitettségüket részlegesen (negyedét-felét) fedezik. Itt is tetten érhető a forint stabilitására vonatkozó motivációs elem, de a nem pénzügyi vállalatokhoz képest kisebb mértékben. 
Mindkét szektor esetében - kvantitatív modellünk alapján - megállapítható, hogy a válságidőszakokban a forint stabilitására játszó forward-kötések mérséklődnek, a forward-állományok árfolyam-érzékenysége csökken. Ez történt idén március folyamán a koronavírus okozta globális pénzügyi piaci turbulencia időszakában is. Márciusban a belföldi szereplők forint melletti kitettségei stagnáltak a forint régiós devizákkal együtt mutatott jelentős gyengülése ellenére: az új kötések csak a lejáratokat fedezték, így a hazai szereplők nem nyújtottak támaszt a forintnak. A forint elleni oldal állománya ugyanakkor gyorsan növekedett nagyrészt a befektetési alapok körében, amit kezdetben az óvatosság motívuma és a nemzetközi devizaeszközökön elszenvedett veszteségek, majd később likviditási sokkok (befektetési jegyek visszaváltásai, margin callok) indokoltak.

Tanulmányunkhoz képest több irányban tovább lehet menni a devizapiaci folyamatok még alaposabb megértésében. A forward-állományok szektorális bontásával a különböző szereplők aktivitását el tudtuk különíteni, ugyanakkor a piac további, egyedi szereplőkre bontott dezaggregálásával lehetne igazán pontosan megérteni a résztvevő́k motivációit. Tanulmányunk hangsúlyosan a határidős devizapiaci kitettségekre fókuszál, a teljes devizapiaci kép feltárását erősítheti az egyéb mérlegbeli és mérleg alatti devizakitettségek együttes elemzése.

\section{Felhasznált irodalom}

Allayannis, G. - Lel, U. - Miller, D.P. (2012): The use of foreign currency derivatives, corporate governance, and firm value around the world. Journal of International Economics, 87(1): 65-79. https://doi.org/10.1016/j.jinteco.2011.12.003

Au, R. - Somefun, K. (2018): Currency risk: full hedging? Or is partial (or no) hedging better? Investors' Corner, BNP Paribas. https://investors-corner.bnpparibas-am.com/investing/ currency-risk-full-hedging/\#_ftnref1. Letöltés ideje: 2020. július 23.

Barroso, P. - Santa-Clara, P. (2015): Beyond the Carry Trade: Optimal Currency Portfolios. Journal of Financial and Quantitative Analysis. 50(5): 1037-1056. http://doi.org/10.1017/ S0022109015000460

Banai Ádám - Kollarik András - Szabó-Solticzky András (2013): Az egynapos FX-swap piacok topológiája. MNB tanulmányok 108, Magyar Nemzeti Bank.

BIS (2019a): Triennial Central Bank Survey of Foreign Exchange and Over-the-counter (OTC) Derivatives Markets in 2019. https://www.bis.org/statistics/rpfx19.htm. Letöltés ideje: 2020. július 23.

BIS (2019b): BIS Quarterly Review December, 2019. www.bis.org/publ/qtrpdf/r_qt1912.html. Letöltés ideje: 2020. július 23. 
Bodnár Katalin (2006): A hazai kis- és középvállalatok árfolyamkitettsége, devizahitelezésük pénzügyi stabilitási kockázatai - Egy kérdőíves felmérés eredményei. MNB tanulmányok 53, Magyar Nemzeti Bank.

Bodnár Katalin (2009): Exchange rate exposure of Hungarian enterprises - results of a survey. MNB Occasional Paper series, No. 80, Magyar Nemzeti Bank. https://www.mnb.hu/en/ publications/studies-publications-statistics/occasional-papers/op80-katalin-bodnarexchange-rate-exposure-of-hungarian-enterprises-results-of-a-survey. Letöltés ideje: 2020. július 23.

Borio, C. - McCauley, R. - McGuire, P. (2017): FX swaps and forwards: missing global debt? BIS Quarterly Review, (September): 37-54. https://papers.ssrn.com/sol3/papers. cfm?abstract_id=3041870. Letöltés ideje: 2020. július 23.

Csávás Csaba - Gereben Áron (2005): Hagyományos és egzotikus opciók a magyar devizapiacon. MNB múhelytanulmányok 35, Magyar Nemzeti Bank.

Csávás Csaba - Kóczán Gergely - Varga Lóránt (2006): A föbb hazai pénzügyi piacok meghatározó szereplői és jellemző kereskedési stratégiái. MNB tanulmányok 54, Magyar Nemzeti Bank.

Csávás Csaba - Szabó Rezső (2010): A forint/deviza FX-swap szpredek mozgatórugói a Lehman-csőd utáni időszakban. Hitelintézeti Szemle, 9(6): 566-580.

Dempster, A.P. - Laird, N M. - Rubin, D.B. (1977): Maximum Likelihood from Incomplete Data Via the EM Algorithm. Journal of the Royal Statistical Society: Series B (Methodological), 39(1): 1-22. https://doi.org/10.1111/j.2517-6161.1977.tb01600.x

Endrész, M. - Gyöngyösi, Gy. - Harasztosi, P. (2012): Currency mismatch and the sub-prime crisis: Firm-level stylised facts from Hungary. MNB Working Papers 2012/8, Magyar Nemzeti Bank.

Endrész, M. - Harasztosi, P. (2014): Corporate Foreign Currency Borrowing and Investment. The Case of Hungary. MNB Working Papers 2014/1, Magyar Nemzeti Bank.

Endrész, M. (2020): The Bank Lending Channel During Financial Turmoil. MNB Working Papers 2020/5, Magyar Nemzeti Bank.

Fama, E. (1984): Forward and Spot Exchange Rates. Journal of Monetary Economics, 14(3): 319-338. https://doi.org/10.1016/0304-3932(84)90046-1

Gatopoulos, G. - Loubergé, H. (2013): Combined use of foreign debt and currency derivatives under the threat of currency crises: The case of Latin American firms. Journal of International Money and Finance, 35(June): 54-75. https://doi.org/10.1016/j. jimonfin.2013.01.004 
Géczy, C.C. - Minton, B.A. - Schrand, C.M. (2007): Taking a view: Corporate speculation, governance, and compensation. The Journal of Finance, 62(5): 2405-2443. http://dx.doi. org/10.1111/j.1540-6261.2007.01279.x

Gereben, Á. - Gyomai, Gy. - Kiss M., N. (2006): Customer order flow, information and liquidity on the Hungarian foreign exchange market. MNB Working Papers 2006/8, Magyar Nemzeti Bank.

Geyer-Klingeberg, J. - Hang, M. - Rathgeber, A.W. (2019): What drives financial hedging? A meta-regression analysis of corporate hedging determinants. International Review of Financial Analysis, 61(January): 203-221. https://doi.org/10.1016/j.irfa.2018.11.006

Guay, W. - Kothari, S.P. (2003): How much do firms hedge with derivatives? Journal of Financial Economics, 70(3): 423-461. https://doi.org/10.1016/S0304-405X(03)00179-X

Harasztosi, P. - Kátay, G. (2020): Currency matching by non-financial corporations. Journal of Banking and Finance, 113(April): 105739. https://doi.org/10.1016/j.jbankfin.2020.105739

Jurek, J.W. (2014): Crash-neutral currency carry trades. Journal of Financial Economics, 113(3): 325-347. https://doi.org/10.1016/j.jfineco.2014.05.004

Kim, S.F. - Chance, D.M. (2018): An empirical analysis of corporate currency risk management policies and practices. Pacific-Basin Finance Journal, 47(February): 109-128. https://doi. org/10.1016/j.pacfin.2017.12.004

Kim, W. - Sung, T. (2005): What makes firms manage FX risk? Emerging Markets Review, 6(3): 263-288. https://doi.org/10.1016/j.ememar.2005.06.002

Kocsis Zalán - Csávás Csaba - Mák István - Pulai György (2013): Kamatderivatíva-piacok Magyarországon 2009 és 2012 között a K14-es adatszolgáltatás tükrében. MNB tanulmányok 107, Magyar Nemzeti Bank.

MNB (2020a): Kereskedelmiingatlan-piaci jelentés, 2020. április. Magyar Nemzeti Bank.

MNB (2020b): Versenyképességi jelentés, 2020. július. Magyar Nemzeti Bank.

Massa, M. - Wang, J. - Zhang, H. (2016): Benchmarking and Currency Risk. Journal of Financial and Quantitative Analysis, 51(2): 629-654. https://doi.org/10.1017/ S0022109016000284

Melvin, M. - Prins, J. (2015): Equity hedging and exchange rates at the London $4 \mathrm{pm}$ fix. Journal of Financial Markets, 22(January): 50-72. https://doi.org/10.1016/j. finmar.2014.11.001 
Mun, K-C. (2016): Hedging bank market risk with futures and forwards. The Quarterly Review of Economics and Finance, 61(August): 112-125. https://doi.org/10.1016/j. qref.2015.11.004

Páles Judit - Kuti Zsolt - Csávás Csaba (2010): A devizaswapok szerepe a hazai bankrendszerben és a swappiac válság alatti müködésének vizsgálata. MNB tanulmányok 90, Magyar Nemzeti Bank.

Patel, N. - Xia, D. (2019): Offshore markets drive trading in emerging market currencies. BIS Quarterly Review, December: 53-67.

Pramborg, B. (2005) Foreign exchange risk management by Swedish and Korean nonfinancial firms: A comparative survey, Pacific-Basin Finance Journal, 13(3): 343-366. https://doi. org/10.1016/j.pacfin.2004.04.003

Smith, C.W. - Stulz, R. (1985): The Determinants of Firms' Hedging Policies. Journal of Financial and Quantitative Analysis, 20(4): 391-405. https://doi.org/10.2307/2330757

Schrimpf, A - Sushko, V. (2019): Sizing up global foreign exchange markets. BIS Quarterly Review, December: 21-38.

Vonnák, Dzs. (2018): Why do firms default on their foreign currency loans? The case of Hungary. Journal of International Money and Finance, 86(September): 207-222. https:// doi.org/10.1016/j.jimonfin.2018.05.001

Yu, J. (2013): A sentiment-based explanation of the forward premium puzzle. Journal of Monetary Economics 60(4):474-491. https://doi.org/10.1016/j.jmoneco.2013.04.001 


\section{Függelék}

A Függelékben a 4. fejezetben közölt modell becslésének hátteréről és a becslések robusztusságáról közlünk információt.

\section{Modellspecifikáció és adatok}

A modellt kétféle függő változóval forward-tranzakciókkal (új forward-kötésekkel) és a kint lévő forward-állomány változásával becsüljük külön a forint melletti és forint elleni bruttó szárakra, a főszövegben a forward-állomány változására vonatkozó becsléseket közöljük. Elméletileg mindkét változótípusra gyakorolt árfolyamhatás modellezése indokolható, bár mindkettő tartalmaz egyszerűsítő feltételezést: a különbség lényege a piaci szereplők lejáró állományokkal kapcsolatos viselkedéséből következik. Az új forward-kötések modelljében a lejáró állománnyal a piaci szereplők alapesetben nem foglalkoznak, a kint lévő állomány változásánál viszont az újrakötésük a kiindulópont. Mindkét esetben a logaritmikus forma tűnik indokoltnak: a forward-kötések esetében az eloszlás ferdeségét a logaritmizálás megszünteti és összhangba hozza a szimmetrikus árfolyamváltozással (a lineáris formánál lényegesen magasabb így a megmagyarázott variancia is). Az állományok esetében a logaritmizálás előnye, hogy az állományváltozások abszolút nagyságrendje az állomány időbeli változásával párhuzamosan emelkedik, így a százalékos változások varianciája időben homogénebb. A forward-kötések esetében az időnként új kötés nélküli napok miatt a napi kötési volumeneket a logaritmizálás előtt egy milliárd forinttal megnöveljük (más kiigazítási tényezők használatának sincs érdemi kvalitatív hatása az eredményekre): a Függelékben lineáris és logaritmikus (az említett kiigazítással) formák becsléseit ismertetjük.

Az adatokat tekintve említettük, hogy a D01 jelentésben szereplő szektorális bontást bizonytalanná teszi, hogy a mintában lévő néhány adatszolgáltató bank a pénzügyi ügyfelek egy részét az anonim (másoknál: lakossági-vállalati ügyfelek) között jelenti. A modell becslésében a legprudensebb eljárásnak ezeknek az adatoknak a mintából történő kihagyását tartottuk: ha - ahogyan feltételezhető - ezeknek a kihagyott bankoknak az ügyfelei hasonlóképpen viselkednek, mint a mintában bent tartott bankok ügyfelei, akkor a minta szúkítésének a számunkra érdekes látens paraméterek időbeli alakulására nem lesz hatása (az állományváltozások százalékos formája miatt a becsült paraméterek nagyságában se lenne eltérés).

Az árfolyamváltozást a modellspecifikációnk a forward-változásoktól exogénnek feltételezi. Ennek a feltételnek a sérülése szimultaneitás problémájához vezethet. A feltételezést részben alátámasztja, hogy a globális forintpiachoz mérten lényegesen kisebb a hazai kereskedés volumene, ami mérsékelt hatást valószínűsít. Ugyanakkor a visszahatás lehetőségét nem tudjuk kizárni, és megfelelő instrumentumok hiányában jelenleg identifikálni sem tudjuk. ${ }^{15}$

\footnotetext{
15 Jövőbeli fejlesztésként várhatóan napon belüli tranzakciós adataink is lesznek, ami az időbeliségen keresztül pontosíthatja a (Granger-féle) kauzalitást, illetve lehetővé teheti a Melvin - Prins (2016) tanulmányban használt portfóliófedezettség kiigazításainak identifikációs eszközét. Emellett a D01-adatok granulált - banki ügyfelenkénti - vizsgálatával lehet feltárni a kölcsönhatás különböző csatornáinak erősségét.
} 


\section{Becslés}

A főszövegben leírt állapot-tér modell ismeretlenei a variancia-paraméterek $(R, Q)$ és a $B_{t}$ paraméter vektor momentumai $\mathrm{E}\left[B_{t}\right], \operatorname{Var}\left[B_{t}\right]$. A modellt EM-algoritmussal becsüljük (Dempster et al. 1977). Az algoritmushoz az induló értékeket a 20032005 közötti mintán végzett előzetes becslésekből állítottuk elő a teljes belföldi, nem pénzügyi és pénzügyi változók ügyfélköre esetében, és a 2014-2015 mintát használtuk a befektetési alapok esetében (ezelőtt különösen a devizavételoldalon ritkák a tranzakciók): a modell fix-paraméteres OLS-becslései alapján a reziduumok varianciáját használtuk a mérési egyenlet varianciájának indulásához $\left(R_{0}\right)$ és 200 napos mozgóablakokok alapján becsült OLS-paraméterek változásai alapján inicializáljuk az állapot-paraméterek innovációinak varianciáit $\left(Q_{0}\right)$. A $B_{t}$ paraméterek indulóértékeit $\left(E\left[B_{0}\right]\right)$ is ezekhez a fix-paraméteres OLS-becsléshez igazítjuk, de ennek a kezdőértéknek kevés jelentősége van, mert a $Q$ varianciához mérten nagyságrendekkel nagyobbra állítjuk a kezdőértékkel kapcsolatos bizonytalanságot a következő képlet szerint $\left(\operatorname{Var}\left[B_{0}\right]=R_{0} X^{\prime} X^{-1}\right)$. Ez biztosítja, hogy az indulóértékek csak rövid ideig (gyakorlatilag egy-két hónapig) vannak érzékelhető hatással a filterezett paraméter-idősorokra. A főszövegben 2007-től, illetve a befektetési alapok esetében 2017-től közölt eredmények tehát a $B_{0}$ kezdőértéket nem befolyásolják. $\mathrm{Az} R_{0}, Q_{0}$ indulóértékekhez képest az EM-algoritmussal keresünk megfelelőbb paraméter-értékeket.

Az EM-algoritmus iteratív becslési eljárásában minden iterációs lépésnél az M-lépésekben új (likelihoodot maximalizáló) paraméterbecsléseket szerzünk az $R, Q$ varianciaelemekre az előző lépésbeli $B_{t}$ paraméterek filterezett momentumai ( $E\left[B_{0}\right]$, $\operatorname{Var}\left[B_{0}\right]$ ) alapján. Az E-lépésekben az új $R, Q$ becslések alapján Kalman-filterrel a $B_{t}$ paraméterek új filterezett idősorait állítjuk elő, valamint kiértékeljük a likelihoodot. Az iterációt addig folytatjuk, amíg a likelihood értéke $10^{-6}$ értéknél többet emelkedik. Esetünkben általában 2-3 lépés elég a konvergenciához.

\section{Robusztusságvizsgálat}

Két robusztusságvizsgálatot mutatunk be, az első a felhasznált adatokra, a második a módszerre vonatkozik.

A főszövegben a modell forward-állomány-változások függő változóval becsült verziójának eredményeit ismertettük. A 20. és 21. ábrákon bemutatjuk, hogy a tranzakciós adatok (új forward-kötések) kvalitatíve hasonló eredményekhez vezetnek. 


\section{0. ábra}

Belföldi forward-állományok árfolyam-érzékenysége (forward-kötések)
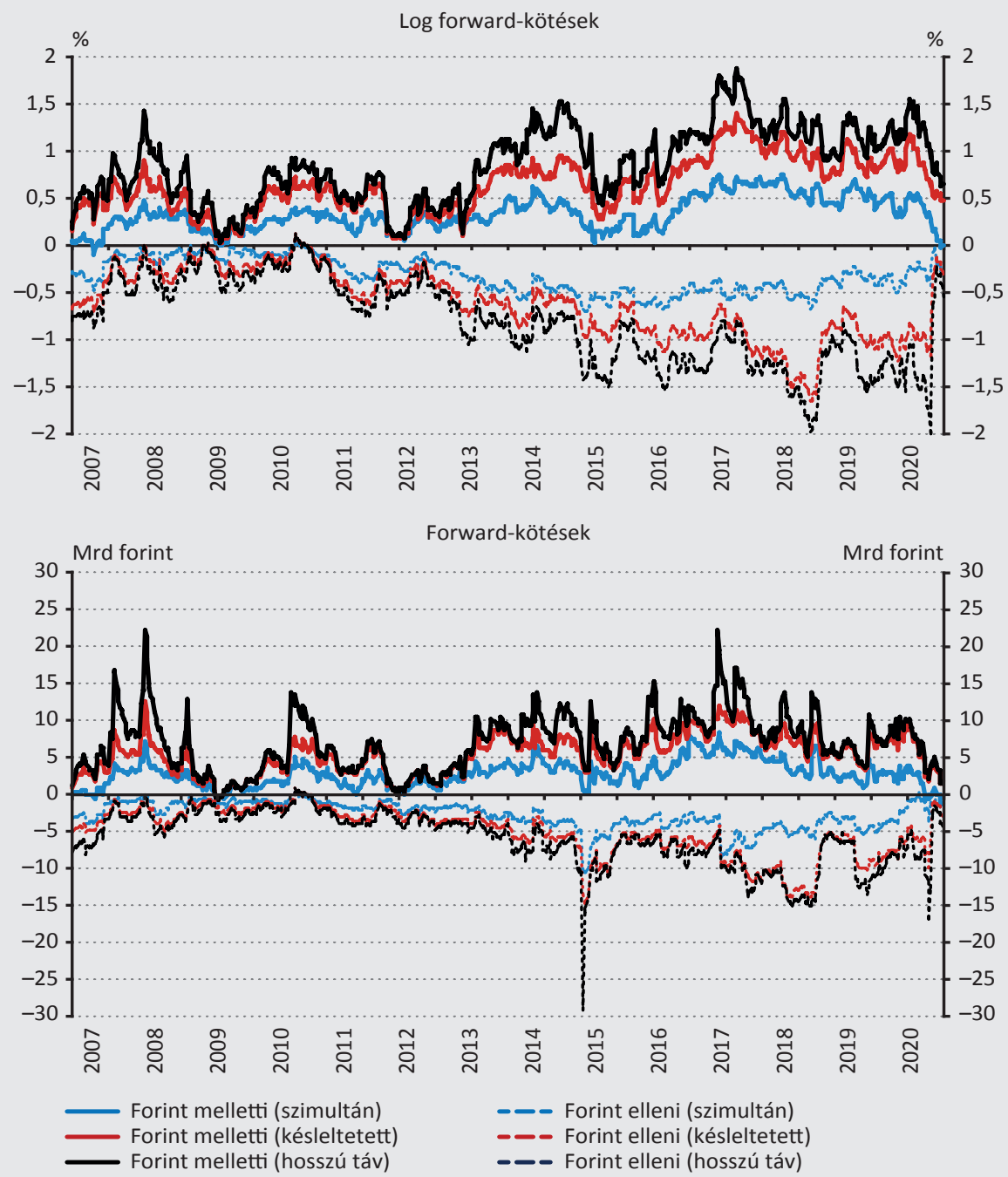

Megjegyzés: Szürt modellparaméterek alapján számított árfolyamérzékenység-idösorok (felső panel: 1 százalékos árfolyamváltozás százalékos hatása a forward-tranzakciók logaritmusára, alsó panel: forintárfolyam-emelkedés hatása a forward-tranzakciókra, milliárd forintban).

Forrás: A MNB (D01) és a Bloomberg adatai alapján számítva 


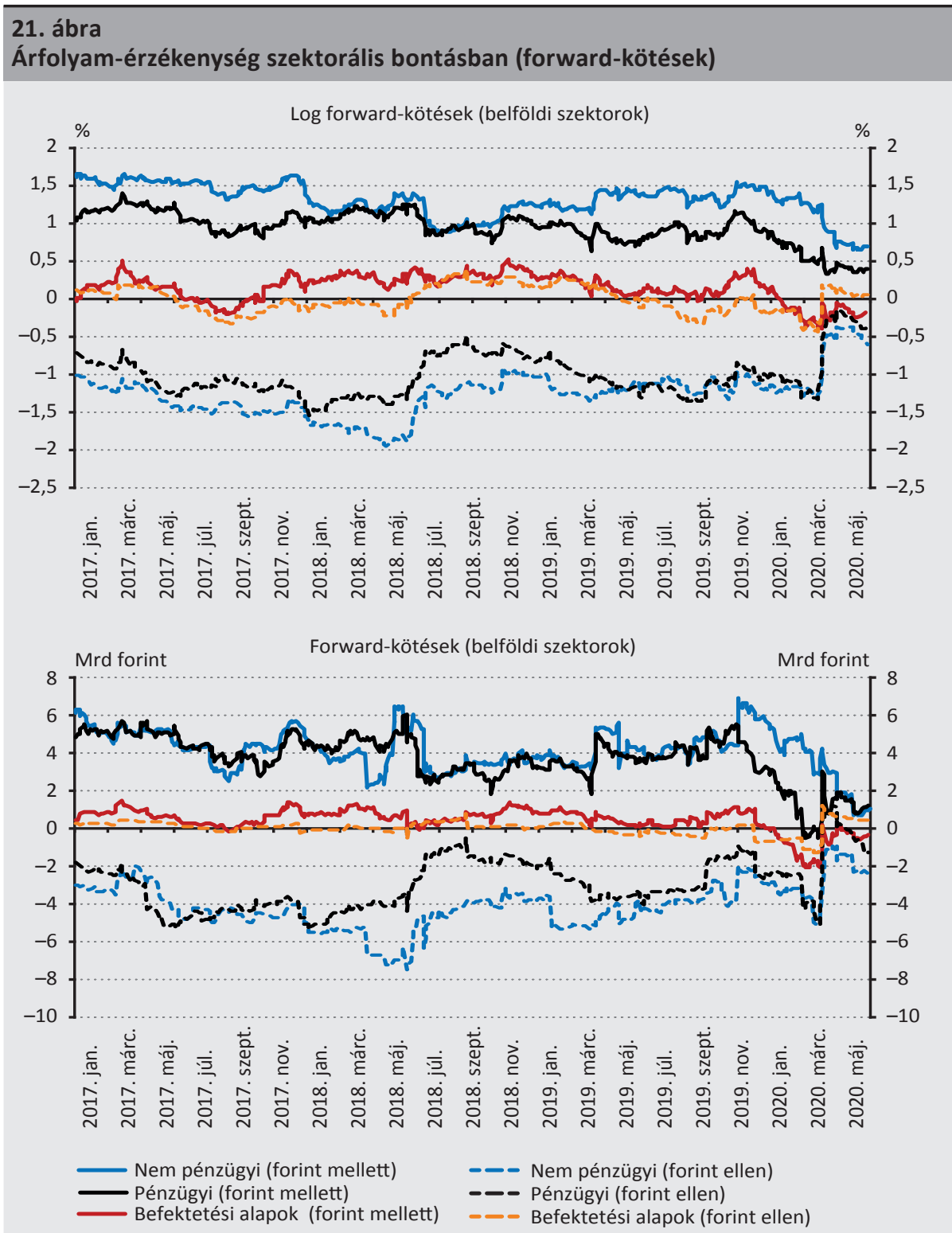

Megjegyzés: Szürt modellparaméterek alapján számított árfolyamérzékenység-idősorok (felső panel: 1 százalékos árfolyamváltozás százalékos hatása a forward-tranzakciók logaritmusára, alsó panel: a forintárfolyam-emelkedés hatása a forward-tranzakciókra, milliárd forintban).

Forrás: Az MNB (D01) és a Bloomberg adatok alapján számítva 


\section{2. ábra}

Belföldi forward-állományok árfolyam-érzékenysége (alternatív módszerek)

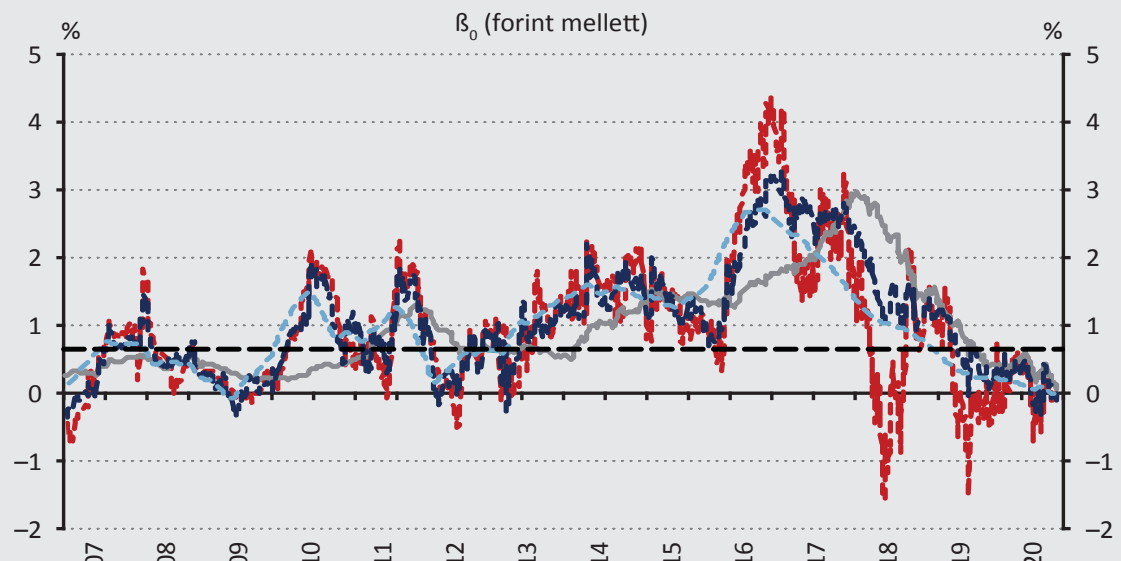

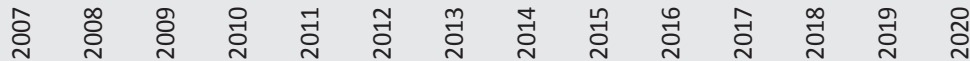

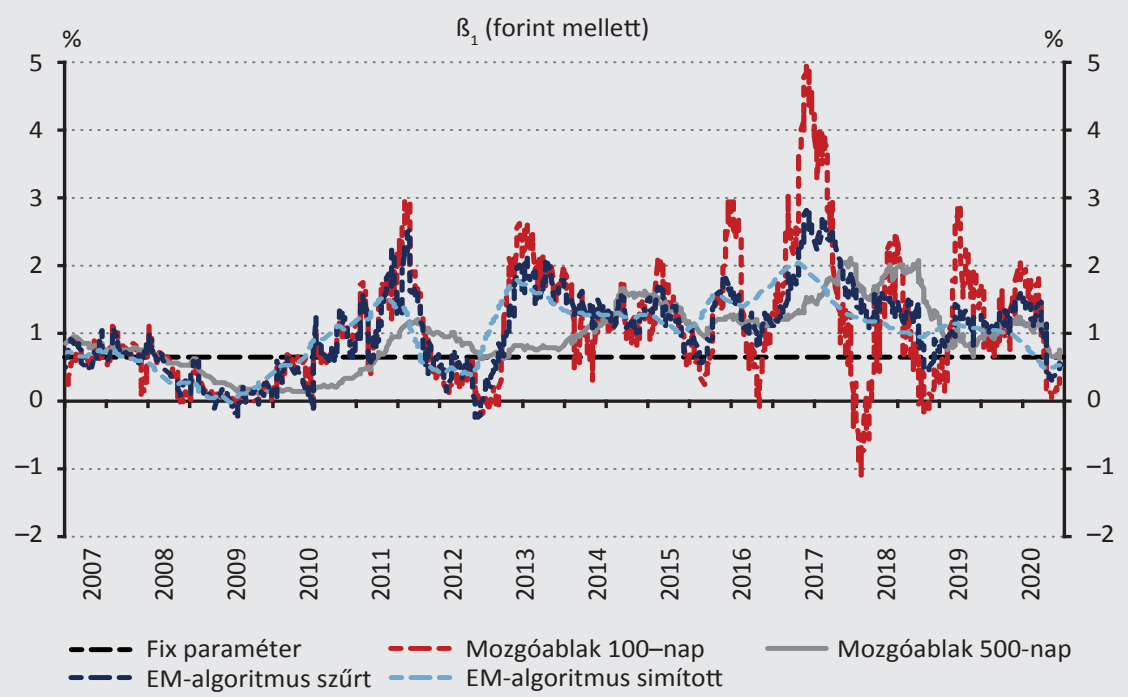




\section{2. ábra (folytatás)}

Belföldi forward-állományok árfolyam-érzékenysége (alternatív módszerek)

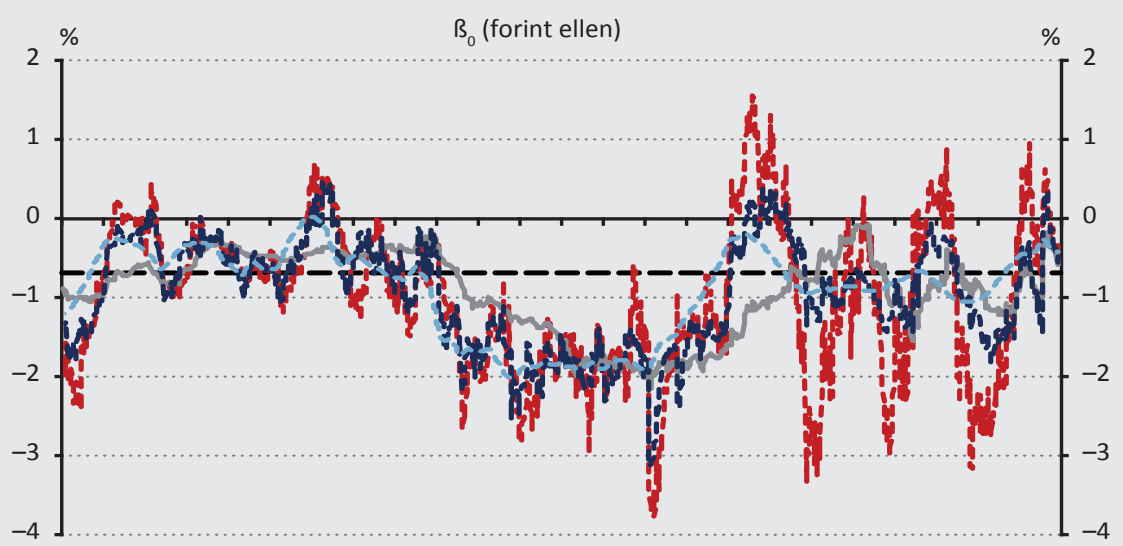

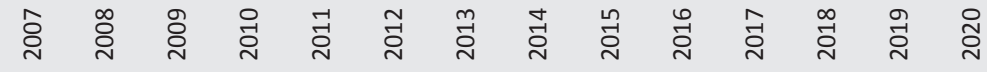

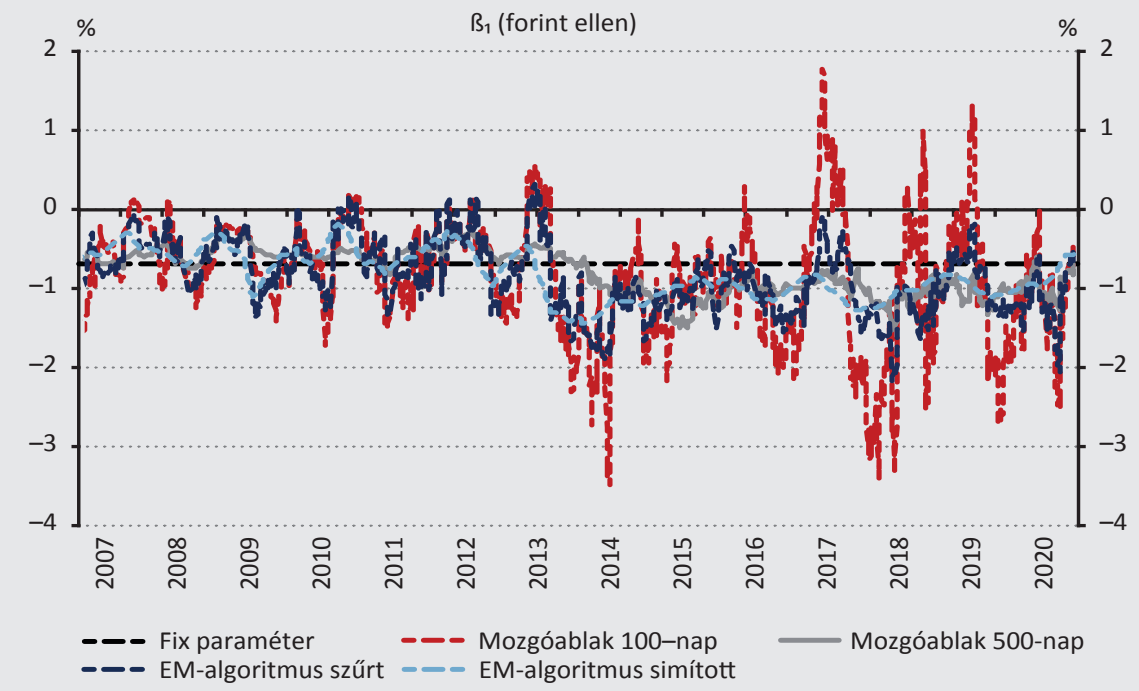

Megjegyzés: OLS becsléssel számított fix és mozgóablakos, illetve EM-algoritmussal számított szürt és simított árfolyamérzékenységi paraméterek idösorai (szimultán és késleltetett hatások a forwardállományra).

Forrás: Az MNB (D01) és a Bloomberg adatai alapján számítva 
Az EM-algoritmus alternativájaként megvizsgáltuk, hogy 100-, illetve 500-napos hosszúságú mozgóablakokon OLS-regresszióval becsült $B_{t}$ paraméter-idősorok mennyire térnek el az általunk alkalmazott szürt paraméterektől. A 22. ábra alapján a mozgóablakos módszer is hasonló tendenciákat tár fel. A különbség abból adódik, hogy az EM-algoritmusban használt Kalman-filter (a modellfeltevések teljesülése esetén) optimális mértékben frissíti az állapotvektort ( $B_{t}$ várható értékét). A mozgóablakos módszer előnye lehet viszont, hogy nem feltételez fix varianciát és a paraméterdinamikára vonatkozóan sem tartalmaz megkötést. A jelenlegi alkalmazásban az EM-algoritmus becslései alkalmasabbak a paraméterek aktuális értékeinek megragadására, a mozgóablakos módszer (erősebb visszatekintő jellege miatt) késve követi az EM-algoritmus becsléseit. 